NBER WORKING PAPER SERIES

\title{
COLLATERALIZED BORROWING AND LIFE-CYCLE PORTFOLIO CHOICE
}

\author{
Paul Willen \\ Felix Kubler \\ Working Paper 12309 \\ http://www.nber.org/papers/w12309
}

\author{
NATIONAL BUREAU OF ECONOMIC RESEARCH \\ 1050 Massachusetts Avenue \\ Cambridge, MA 02138 \\ June 2006
}

The authors thank Chris Carrigan, Daniel Davidson, Kris Gerardi, Jonathan Meer, and Adam Shane for excellent research assistance and George Constantinides, Steve Davis, Peter Fortune, Jeff Fuhrer, Toby Moskowitz, and various seminar participants for comments and suggestions. The views expressed herein reflect the opinions of the authors and not necessarily the opinions of the Boston Fed or the Federal Reserve System. The views expressed herein are those of the author(s) and do not necessarily reflect the views of the National Bureau of Economic Research.

(C2006 by Paul Willen and Felix Kubler. All rights reserved. Short sections of text, not to exceed two paragraphs, may be quoted without explicit permission provided that full credit, including $\odot$ notice, is given to the source. 
Collateralized Borrowing and Life-Cycle Portfolio Choice

Paul Willen and Felix Kubler

NBER Working Paper No. 12309

June 2006

JEL No. G11, D14

\begin{abstract}
$\underline{\text { ABSTRACT }}$
We examine the effects of collateralized borrowing in a realistically parameterized life-cycle portfolio choice problem. We provide basic intuition in a two-period model and then solve a multi-period model computationally. Our analysis provides insights into life-cycle portfolio choice relevant for researchers in macroeconomics and finance. In particular, we show that standard models with unlimited borrowing at the riskless rate dramatically overstate the gains to holding equity when compared with collateral-constrained models. Our results do not depend on the specification of the collateralized borrowing regime: the gains to trading equity remain relatively small even with the unrealistic assumption of unlimited leverage. We argue that our results strengthen the role of borrowing constraints in explaining the portfolio participation puzzle, that is, why most investors do not own stock.
\end{abstract}

Paul S. Willen

Research Department

Federal Reserve Bank of Boston

P.O. Box 55882

Boston, MA 02205

and NBER

paul.willen@bos.frb.org

Felix Kubler

Institut für VWL, Wirtschaftstheorie

Universitaet Mannheim

68131 Mannhein

GERMANY

fkubler@rumms.uni-mannheim.de 


\section{Introduction}

In this paper, we examine the effects of collateralized borrowing in a realistically parameterized life-cycle portfolio choice problem. In doing so, we fill an important gap in the literature. Previous applied researchers have, for reasons of analytical or computational convenience rather than realism, selected from a set of extreme assumptions about collateralized borrowing. Some assumed that investors can borrow unlimited amounts at the riskless rate. Others assumed that investors cannot use any assets as collateral for loans. And yet others assumed nonnegativity of investor net asset positions, implying that investors can use any long position in one asset as collateral for a short position in another. In this paper, we consider a realistic intermediate case: Investors can use some portion (possibly all) of their long positions to borrow at an interest rate that exceeds (at least weakly) the interest rate on a riskless asset.

Investors in our model face a very complex problem. They can engage in secured borrowing at one interest rate, unsecured borrowing at another, and riskless lending at yet a third. They face limits on the ratio of unsecured borrowing to labor income and limits on the ratio of secured borrowing to holdings of the risky asset. Despite these added complexities, we show that one can use a simple back-of-the-envelope approach and get the basic intuition for the solution. Using our back-of-the-envelope approach, we show some simple, somewhat counterintuitive results about the relationship between wealth, income, secured borrowing, and the demand for equity. We then calculate policy rules and explore the distribution of portfolio choices using a computational model.

Our analysis provides insights into life-cycle portfolio choice relevant for researchers in macroeconomics and finance. In particular, we show that standard models with unlimited borrowing at the riskless rate dramatically overstate the gains to holding equity when compared with models with even an unrealistically generous collateralized borrowing regime. Further, we show that with a realistic collateralized borrowing regime, the gains to holding equity over the life cycle exceed by only a narrow margin the gains to holding equity in a model with no uncollateralized borrowing at all.

Our results significantly strengthen the role of borrowing constraints in explaining why most investors do not hold stock, a phenomenon often referred to as "the participation puzzle." In a series of recent papers, researchers have shown that when investors face borrowing constraints, investors gain so little from trade in equity that relatively small transactions, or participation or information costs, can explain why they forsake equity altogether. But to generate these results, all the researchers as-

sume that investors cannot use long positions in equity as collateral for loans, one of 
the extreme assumptions about collateralized borrowing discussed above. Critics have argued that relaxation of that assumption would overturn borrowing constraints as an explanation of the participation puzzle. Our results do not support this criticism. With realistic levels of collateralized borrowing, the gains to holding equity remain small.

In modeling the life-cycle consumption problem, we choose to ignore the role of housing, an omission that requires an explanation, as housing accounts for a large fraction of the collateralized borrowing conducted by households. The goal of this paper is not to provide a comprehensive theoretical description of the household portfolio decision, but to ask how the ability to leverage equity holdings through collateral affects the demand for equity and the gains to trading it. Not only does housing not directly affect that question, but if we added housing to our model, we would then have to disentangle the effects of housing and the effects of collateralized borrowing on equity demand. Put another way, in this paper we address a criticism of research that, with a few exceptions, ignores housing as well. In no way should the above suggest that we think housing is unimportant to household portfolio choice or to the demand for equity. On the contrary, the small gains to trade in equity revealed in this paper illustrate the misguidedness of the traditional focus on stocks and bonds in household portfolio choice problems. In other work [Kubler and Willen (2006)], we directly address the question of housing collateral in a multi-asset version of the model developed here.

Our work also adds to recent work on the "limits of arbitrage." Typically, such work focuses on limits to theoretically profitable strategies faced by highly sophisticated, wealthy investors. ${ }^{1}$ We show below that these portfolio limitations present an even more serious problem for the small investor when he or she tries to "arbitrage" the risk-adjusted returns on different assets.

The paper proceeds as follows. In the remainder of the introduction, we conduct a literature review, exploring in detail the different approaches to collateralized borrowing mentioned above. In Section 2, we present the model and our simple backof-the-envelope approach for analyzing consumption-portfolio problems with risky assets and collateralized and uncollateralized borrowing in a two-period model.

In the rest of the paper, we focus on measuring the quantitative importance of collateralized borrowing in our model. To do this, we first need to get some idea of opportunities for using equity as collateral for loans in the real world, starting with margin loans and moving to more indirect methods like futures and mutual funds that

\footnotetext{
${ }^{1}$ For examples, see Shleifer and Vishny (1997), Gabaix, Krishnamurthy, and Vigneron (2006), and Geanakoplos (2003).
} 
invest in options to get leverage. In Section 3, we conclude that investors can easily use at least half their investment as collateral (and thus get at least 2:1 leverage), but the interest rate on such borrowing (either explicitly or implicitly) exceeds the interest rate on riskless investment by a particularly wide margin for small investors.

In Section 4, we develop our multi-period life-cycle model, calculate policy rules, and run simulations. We show that with what we consider realistic borrowing regimes, the gains to trading equity are small. One example we consider involves an investor with a relative risk aversion coefficient of 3 and an equity premium of 4 percent. Suppose an investor can use 75 percent of his or her equity holdings as collateral for a loan at an interest rate 100 basis points above the riskless rate, a very generous borrowing regime, as our evidence in Section 3 shows. Further, our investor can borrow as much as one year's labor income without security at an interest rate 800 basis points above the riskless rate. Under these conditions, the ability to trade equity raises lifetime certain-equivalent consumption by less than 2 percent. To put this in perspective, a model with unlimited borrowing and lending at the riskless rate yields gains to trading equity of 25 percent of lifetime consumption (under the maintained assumptions). What accounts for the gap? We show that realistic limits to collateralized borrowing account for only a small part. If investors could use all their equity holdings as collateral for loans and borrow at the riskless rate, lifetime certain-equivalent consumption would rise by 6.7 percent, narrowing the gap by only about a fifth. Our assumptions about unsecured borrowing account for the rest of the gap. The key insight is that to fully exploit collateralized borrowing, one must also be able to take out unsecured loans, both to consume future excess returns on equity and to smooth adverse stock return outcomes.

In Section 5, we briefly explore the extent of collateralized borrowing against equity. Consistent with our results, we find that investors engage in practically none. According to the Survey of Consumer Finances (SCF), fewer than 1 percent of investors took out margin loans in 1998. Among households that held stock, around 4 percent took out margin loans, and the average value of those loans was only $\$ 844$. In Section 6, we address the participation puzzle, and a brief conclusion follows in Section 7.

\subsection{Literature Review}

In the classical theoretical literature on life-cycle portfolio choice, researchers assume that investors can borrow unlimited amounts at the riskless rate. Both Merton (1969) and Samuelson (1969) make such assumptions in their path-breaking works. The most important paper on portfolio choice in the intervening 40 years, Cox and Huang's 
(1989) martingale approach, continues in that tradition. The vast majority of applied researchers on portfolio choice still work in this framework [see Brandt (2005) for a survey].

Starting in the late 1980s, researchers developed theoretical models with more realistic borrowing regimes. Researchers adopted many different approaches, but three basic types emerged.

The first approach restricts investors' holdings of each asset separately. For example, we might prohibit short sales of stocks and bonds and allow borrowing, but at a high interest rate. The key here is that restrictions on holdings of one asset are independent of restrictions on holdings of any other asset. So, even if you held a large position in bonds, you would still not be able to sell stocks short. Examples of this approach include work by Heaton and Lucas (1997, 2000), Cocco, Gomes, and Maenhout (2005), Gomes and Michaelides (2005), Davis, Kubler, and Willen (2006), and others.

The second approach is to require that investors maintain positive wealth. In other words, one can hold a short position in one asset so long as one has an offsetting long position in something else. So, one can use 100 percent of a long position in an asset as collateral for a loan. Late-night television audiences would recognize such "No Money Down" investment opportunities. Wall Streeters would say that investors in such models can buy assets without any haircut. Examples of this approach include He and Pearson (1991b), He and Pagès (1993), El-Karoui and Jeanblanc-Picqué (1998), and Detemple and Serrat (2003).

The third approach, and the focus of this paper, is essentially a combination of the first two. Investors face constraints on holdings of specific assets that depend on their holdings of other assets. For example, investors can take out low-interest collateralized loans, but markets limit such loans to a specific fraction of their long position in another asset. Such an intermediate approach preserves the flavor of the first approach — specific limits on individual assets - while adopting some of the flavor of the second, as investors can use long positions to at least partially offset short positions. Examples of this approach include Cuoco (1997), He and Pearson (1991a,b), Cvitanić and Karatzas (1992), Vila and Zariphopolou (1997), Tepla (2000), and Grossman and Vila (1992).

Some researchers have addressed the issue of collateralized borrowing explicitly. Both Grossman and Vila (1992) and Vila and Zariphopoulou (1997) consider a borrowing regime similar to ours in which investors can use some fraction of their stock holdings as collateral for loans. But both models diverge from ours in that they assume that investors receive no non-capital income, and in neither paper do the 
authors attempt to assess the quantitative importance of collateral restrictions.

A few papers [Cocco (2005), Yao and Zhang (2005)] consider models with risky assets and housing, in which investors can use housing as collateral for loans. The authors draw attention to the effect of the housing investment on equity demand. We address a completely different question: the effect on portfolio choice of using the equity itself as collateral for loans.

We note several other papers in which researchers address the issue of collateralized borrowing. Constantinides, Donaldson, and Mehra (2002) allow investors to use up to 98 percent of a investor's equity holdings as collateral for low-interest loans in a dynamic overlapping-generations model. They find that such a borrowing opportunity has little or no effect on equilibrium asset prices. Finally, Fortune (2000, 2003) discusses margin loans and other leverage methods. The reader should consult these papers for a more detailed discussion of the issues addressed in Section 3.

\section{The Model and Basic Intuition}

We consider a partial-equilibrium model of investor consumption and portfolio choice. Our model builds on the framework developed in Davis, Kubler, and Willen (2006). As in that paper, we consider finitely lived investors who receive labor income, invest in assets, and borrow.

Investors receive labor income from age 22 to age 65 , retire and receive a constant fraction of labor income in the last year of work, and die at age 80. We calculate this fraction so that, on average, an investor receives a constant fraction of the last $n$ years of labor income. For details on this procedure, see Davis, Kubler, and Willen (2006). Unlike that paper, we assume that labor income evolves non-stochastically. It is possible to solve the model with stochastic labor income, but we opted against doing so in order to focus attention on collateralized borrowing in what is already a complicated model.

Investors can trade four financial assets. They can buy equity $(E)$ with stochastic return $\tilde{R}_{E}$, save $(L)$ at a net risk-free rate $R_{L}$, engage in uncollateralized borrowing $(U)$ at the rate $R_{U} \geq R_{L}$, and engage in collateralized borrowing $(S)$ at the rate $R_{S}$, where $R_{L} \leq R_{S} \leq R_{U}$. We will often refer to the net returns on these assets, which 
we will denote by a lower case $r$. The investor's budget constraint at time $t$ is

$$
\begin{gathered}
\underbrace{c_{t}}_{\text {Consumption }}+\underbrace{E_{t}}_{\text {Equity }}+\underbrace{L_{t}}_{\text {Saving }}-\underbrace{U_{t}}_{\begin{array}{c}
\text { Unsecured } \\
\text { borrowing }
\end{array}}-\underbrace{S_{t}}_{\begin{array}{c}
\text { Secured } \\
\text { borrowing }
\end{array}}= \\
\underbrace{y_{t}}_{\substack{\text { Labor } \\
\text { income }}}+R_{E} E_{t-1}+R_{L} L_{t-1}-R_{U} U_{t-1}-R_{S} S_{t-1} .
\end{gathered}
$$

We assume that the investor cannot die in debt, so $U_{T}=S_{T}=0$.

Uncollateralized borrowing cannot exceed some fraction $B L$ of current labor income, although we sometimes set $B L=\infty$. Collateralized borrowing works as follows. Let $\delta$ be the required down-payment on a dollar of equity. Let $E_{t}$ be equity holdings and $S_{t}$ be collateralized debt at time $t$. Then:

$$
S_{t} \leq(1-\delta) E_{t}
$$

Using our notation, one could say that we permit no short sales of any assets. In other words, one cannot borrow at $R_{L}$ or save at $R_{U}$ or $R_{S}$. But if one views both secured and unsecured borrowing as short positions in the riskless asset, then one can view our portfolio restrictions as similar to those used by, for example, He and Pearson (1991b), as discussed in the literature review.

An investor chooses a contingency plan for consumption, borrowing, and asset holdings at date $t$ to maximize

$$
U\left(c_{t}\right)+\mathrm{E}_{t} \sum_{a=t+1}^{T}(1 / \beta)^{a-t} U\left(\tilde{c}_{a}\right)
$$

subject to a sequence of budget constraints, where $c_{a}$ is consumption at age $a, \mathrm{E}_{t}$ is the expectations operator conditional on time- $t$ information, $1 / \beta$ is a time discount factor, and $U(\cdot)$ is an isoelastic utility function. We solve numerically for the optimal solution using a backward-induction algorithm, similar to that described in the appendix of Davis, Kubler, and Willen (2006).

\subsection{Basic Insights}

We proceed in three steps. First, we provide a basic overview of the intuition for our results. Second, we discuss them more formally in the context of a two-period model. Third, we discuss how the simple mechanisms discussed interact in a dynamic context. In Section 4, we measure the quantitative significance of the effects in realistically parameterized examples. 
We characterize portfolio choice using a simple rule: If and only if the risk-adjusted return on an asset exceeds (falls short of, equals) the rate at which one discounts riskless future consumption, should one add to (subtract from, not change) one's position in that asset. Before continuing, we need to explain how we calculate "risk-adjusted return." For each state of nature, we multiply the probability of the state by the marginal utility of an investor's consumption in that state and then renormalize to create a new probability vector, the "risk-neutral" or "martingale" probabilities. The risk-adjusted return is the expected return calculated using the risk-neutral probabilities. To see how this works, suppose we have two states of nature both of which occur with true probability 0.5 , and an investor with high income in one state and low income in the other. Since the marginal utility of consumption is higher in the low-income state, we assign a risk-neutral probability of more than 0.5 to it, say 0.75 for the purpose of discussion, and, correspondingly, a probability of 0.25 to the high-income state. Suppose that we have an asset which returns 100 percent in the high-income state and zero percent in the low-income state. The true probabilities yield an expected return of 50 percent for this asset, but the risk-neutral probabilities generate a risk-adjusted return of only 25 percent, because we assign 75 percent of the probability to the low-income state, in which the asset pays 0 percent. As we show below, constraint means that risk neutral probabilities differ across investors, and, for a given investor, differ across wealth levels. For a more complete discussion of the topic, see He and Pearson (1991b).

It is easy to understand classical unconstrained portfolio theory using this rule: If one can buy and sell unlimited quantities of all assets, then portfolio choice satisfies optimality if and only if the risk-adjusted returns on all assets equal the individual discount rate, and thus, each other. Otherwise, the rule says to buy more or less of the asset, contradicting the optimality of the allocation. And, if one can trade a riskless asset whose risk-adjusted return equals its observed return, then we know that the risk-adjusted return of all assets must equal the return on that riskless asset, and that return must equal the individual discount rate.

But borrowing and short-sales constraints, at first blush, confound the rule. Suppose, for example, that the risk-adjusted return on equity exceeds both the discount rate and the return on the riskless bond. The simple rule from above says: Buy more! But suppose one has already allocated all of one's money to equity; what then? One solution would be to short the riskless bond, but we have assumed that one cannot. Another solution would be to take out an unsecured loan, but then one would be buying less of a bond, so one needs to be sure that the discount rate exceeds the return on the bond, because, following our simple rule, one should buy less of an asset only 
if the risk-adjusted return falls short of the discount rate. What about secured debt?

We will show below that we can apply the basic rule from above to our problem by making a few adjustments. First, we show that our adjustments for both risk and the discount rate depend on how much financial wealth a household has, conditional on a given income process. Second, at an optimum, the risk-adjusted returns will typically differ across assets. Third, in measuring the risk-adjusted return on an asset, we will need to take into account both the direct returns in the form of higher future income and the indirect returns that arise from the effect on limits of holding a particular asset versus holding a different asset: If we can use an asset as collateral for a loan, then it yields a shadow benefit of enabling low-cost credit.

To fix our intuition we consider a two-period model. The Euler equation for unsecured borrowing is:

$$
u^{\prime}\left(c_{0}\right)-R_{U} \mathrm{E}\left[u^{\prime}\left(\tilde{c}_{1}\right)\right]+\lambda_{U}-\lambda_{B L}=0
$$

where $\lambda_{U}$ are $\lambda_{B L}$ are Lagrange multipliers for the no-short-sales and borrowing constraints, respectively. For secured debt, we get:

$$
u^{\prime}\left(c_{0}\right)-R_{S} \mathrm{E}\left[u^{\prime}\left(\tilde{c}_{1}\right)\right]+\lambda_{S}-\lambda_{S E}=0
$$

where $\lambda_{S}$ are $\lambda_{S E}$ are Lagrange multipliers for the no-short-sales and collateral constraints, respectively. For the riskless asset, we get:

$$
u^{\prime}\left(c_{0}\right)-R_{L} \mathrm{E}\left[u^{\prime}\left(\tilde{c}_{1}\right)\right]-\lambda_{L}=0
$$

where $\lambda_{L}$ is the Lagrange multiplier for the no-short-sales constraint. Finally, for equity we get:

$$
u^{\prime}\left(c_{0}\right)-\mathrm{E}\left[\tilde{R}_{E} u^{\prime}\left(\tilde{c}_{1}\right)\right]-\lambda_{E}-(1-\delta) \lambda_{S E}=0,
$$

where $\lambda_{E}$ are $\lambda_{S E}$ are Lagrange multipliers for the no-short-sales and collateral constraints, respectively. The usual complementary-slackness and non-negativity conditions also apply.

We can collapse the Euler equations into a single inequality that holds for any asset:

$$
\frac{u^{\prime}\left(c_{0}\right)}{\mathrm{E}\left(u^{\prime}\left(c_{1}\right)\right)} \equiv 1+r \gtreqless \mathrm{E}_{Q}\left[\tilde{R}_{i}\right]
$$

where $E_{Q}$ is the expectation with respect to the martingale probabilities defined by the vector of investor marginal utilities. The quantity $\mathrm{E}_{Q}\left[\tilde{R}_{i}\right]$ is the formal definition of "risk-adjusted return," mentioned above. The direction of the inequality depends on which constraints bind. If no constraints bind, then equation (5) holds with equality and we get our standard consumption-based asset-pricing result. But constraints lead 
to inequality. Suppose the no-short-sales constraint holds on the riskless bond. Since the expectations under the martingale probabilities and the true probabilities are the same for a riskless asset, equation (3) implies that:

$$
\frac{u^{\prime}\left(c_{0}\right)}{\mathrm{E}\left(u^{\prime}\left(c_{1}\right)\right)}=1+r=\mathrm{E}_{Q}\left[R_{L}\right]+\lambda_{L}>R_{L} .
$$

Only one asset, or pair of assets, presents a problem: secured debt and equity. As we mentioned before, equity provides extra benefits in the form of relief from high interest rates or limited debt. How do we integrate that with our pricing equation (5)? If we assume that short-sales constraints on the two assets do not bind, then we can substitute the collateral constraints from equations (2) and (4) to get:

$$
u^{\prime}\left(c_{0}\right)-\mathrm{E}\left[\left((1 / \delta) \tilde{R}_{E}-(1 / \delta-1) R_{S}\right) u^{\prime}\left(\tilde{c}_{1}\right)\right]=0
$$

Equation (7) implies that, in addition to the four assets under consideration, we can add a fifth, a portfolio of $1 / \delta$ dollars of equity financed by $1 / \delta-1$ dollars of secured debt. Note that this asset has a price of one dollar and has a convenient interpretation: It is a fully leveraged stock portfolio or, as we will call it, the FLP.

We now consider a two-period-lived investor who receives 10 dollars in lifetime income, discounted at the riskless rate $r_{L}$, and two of those dollars this year. In addition, we endow the investors with a certain amount of additional first-period wealth. The investor has a utility function, isoelastic across periods, with relative risk aversion coefficient of 3 . We set $r_{U}=10$ percent, $r_{L}=2$ percent, $\mathrm{E}\left(\tilde{r}_{E}\right)=8$ percent, and $r_{S}=5$ percent. We limit unsecured borrowing to one year's income and require a 20 percent down-payment on any risky investment, implying that one can use 80 percent of an asset as collateral for a loan.

Figure 1 shows portfolio choice in this example for different levels of wealth. The top half of the figure shows the discount rate and risk-adjusted returns for the different assets. The bottom half shows demand for different types of assets. We call this picture the "portfolio stairs" because of the shape of the path of the discount rate. We first consider investors with very little current wealth, to the left of wealth level $A$ on the $x$-axis. The individual discount rate is extremely high for low levels of wealth, exceeding the return on all assets including the FLP (which yields 20 percent). Thus, if we removed constraints, these investors would try to short everything, including equity and even the FLP. To confirm the theory, investors max out on unsecured debt, the only asset they can actually short. As wealth increases, investors allocate it entirely to current consumption, driving down the discount rate, so that the discount rate line intersects the FLP return line at the point labelled $A^{*}$. 
To the immediate right of wealth level $A$, investors initiate purchases of the FLP. Equation (7) holds, and the discount-rate line coincides with the risk-adjusted FLP line. But now, as holdings of the risky asset increase, the implied martingale probabilities change and the risk-adjusted return to equity and the FLP fall.

The discount rate reaches 10 percent at the point $B^{*}$. To the immediate right of wealth level $B$, investors use additional wealth to pay off unsecured debt. In addition, they invest a small portion of additional wealth in the fully leveraged portfolio. Since no constraints are binding on either the FLP or unsecured debt, the discount rate equals the return on the FLP and the return on unsecured debt.

Between wealth levels $B$ and $C$ on the $x$-axis, investors use most of their incremental wealth to reduce unsecured debt and add a small amount to the FLP. At wealth level $C$, all unsecured debt is paid off, and investors again start adding to equity in earnest. Increased equity investment reduces the risk-adjusted return on the FLP until the discount rate reaches 5 percent, the return on the secured debt. Now, investors start to pay off the secured debt. At wealth level $D$, investors hold three different assets: secured debt, equity, and the FLP. To see why, note that any partially leveraged portfolio equals a portfolio composed of equity and the fully leveraged portfolio. Thus, neither the short sale nor the collateral constraint binds any longer.

At point $E^{*}$, the risk-adjusted return on the FLP falls below the discount rate, and investors no longer engage in borrowing. To the right of wealth level $E$, investors invest only in equity until both the risk-adjusted return on equity and the discount rate reach the return on the riskless bond, just as in the standard model described at the beginning of this section.

What do the portfolio stairs tell us? First, they show that in the presence of margin requirements, sufficiently low wealth always chokes off equity demand. If we assume that the marginal utility of consumption blasts off to infinity as consumption approaches zero, some sufficiently low level of wealth always yields a discount rate that exceeds any given return on the fully leveraged portfolio.

Second, we learn that equity demand is not linear at all in wealth, nor does it even vary smoothly with wealth. Equity demand is more sensitive to increases in wealth at high and low levels of wealth than in between. At low levels of wealth, the risk-adjusted returns to the fully leveraged portfolio make equity more attractive than paying off debt. For moderate levels of wealth, the opposite is true. When the unsecured debt is paid off, equity demand grows rapidly.

Third, they illustrate the value of the fully leveraged portfolio as a simple measure of the importance of leverage. For low levels of wealth, the FLP offers a summary 
statistic for the opportunity to invest in equity.

Fourth, a change in the borrowing interest rate affects equity demand, even though investors can buy equity without taking out an unsecured loan.

We draw the reader's attention to three subtle issues in the model. First, what happens in the extreme case where $\delta=0$ ? Equation (7) isn't much use, but equations (2) and (3) imply that:

$$
E_{Q}\left(\tilde{R}_{E}\right)=R_{S}
$$

at an optimum. Equation (8) is no different from the corresponding equation in a model with no constraints at all, at least for these two assets. Does that mean that we can ignore the rest of the model? Not entirely. Purchases of unsecured debt affect future consumption and thus the martingale probabilities. Consider the following simple example. Suppose the unsecured borrowing constraint binds and we raise the interest rate by a tiny amount. Borrowing stays the same, but the level of future consumption falls, which will generally skew the risk-neutral probabilities toward the bad states, lowering the risk-adjusted return and reducing equity demand. Alternatively, if we hold the interest rate fixed and lower the borrowing limit, we raise future consumption, which, following the same logic, should raise equity demand.

Second, unsecured borrowing affects the welfare benefits of investing in risky assets. If an investor faces no margin requirements, he or she faces no limit on equity purchases. But when the investor realizes the benefits of the equity depends on whether he or she can borrow. Buying lots of equity drives up consumption in period 1 , but if, say, the investor faces a fixed borrowing limit, then the benefits accrue only in the future, and with fixed current consumption, generate diminishing marginal returns.

Third, when we move to a multi-period model, the role of unsecured borrowing expands. In the two-period model, unsecured borrowing facilitates consumption smoothing and investment in the risky asset (or the FLP). But in a multi-period model, unsecured borrowing at future dates allows a household to smooth adverse asset-return outcomes in the future. In the context of our discussion above, such smoothing moves the martingale probabilities closer to the true probabilities and increases equity demand.

These last three points illustrate one of the key points of the paper: Even in the presence of unlimited margin borrowing, unsecured credit availability still matters to both the level and the welfare benefits of equity ownership. We return to this point when we consider the simulations. 


\subsection{Modeling borrowing constraints}

In the literature review, we argued that a realistic treatment of borrowing in portfolio choice models requires that we eschew asset-by-asset restrictions in favor of crossasset restrictions. In other words, we do not forbid borrowing altogether, but rather require that borrowers combine their short positions in the riskless asset with long positions in something else. But among the universe of cross-asset restrictions, we chose a particular version and we now attempt to justify that choice. We believe our approach represents the best combination of tractability and realism, but we acknowledge its shortcomings. Our approach basically says that borrowers can use some fraction of their long position in a risky asset to offset a short position in the riskless asset and get a lower interest rate. We ignore the possibility of shorting the risky asset here for now.

One alternative to our approach is a "market wealth" constraint, using the terminology of Luttmer (1996), which says that the value of a purchased portfolio must exceed zero. A market wealth constraint is actually a special case of our setup in which the fraction of long position usable as collateral is 100 percent and the interest rate on secured borrowing equals the rate on riskless lending. The market wealth constraint is unrealistically generous. Even hedge funds cannot get 0-percent haircuts and our discussion in the next section demonstrates that the average investor cannot get anything close to what hedge fund managers get.

Another alternative is a "solvency" constraint, again using Luttmer's terminology, which says that an investor cannot buy a portfolio that generates a negative payoff in any state of the world in the future. Lustig (2004) explicitly justifies a solvency constraint as emerging endogenously in a model in which investors can file for bankruptcy and the lenders seize all their assets but impose no other punishments. And such a constraint also emerges from Geanakoplos and Zame's (2002) setup. Solvency constraints seems somewhat more realistic than a market wealth constraint but they often prove too restrictive. Essentially, they say that you cannot borrow more than the worst possible outcome of an asset. As Merton (1975) points out, in a discrete time model with lognormally distributed returns, the worst possible outcome is arbitrarily small, and in such a model, a solvency constraint is equivalent to the restriction that no one can borrow at all. Solvency constraints are also a special case of our model if we set the collateral requirement equal to return of the asset in the worst possible state and set the interest rate equal to the riskless rate.

To further complicate matters, both market wealth and solvency constraint approaches are unrealistically restrictive in that they forbid unsecured borrowing altogether. As we show below, the ability to take out unsecured loans dramatically 
affects the attractiveness of equity and of secured loans. To see how unsecured borrowing affects the situation, think of a margin loan. With a margin loan (described in detail in Section 3.1), brokerages allow investors to borrow up to 50 percent of the value of their stock holdings, but they retain the power to sell the stock in the event that the net position falls below some prespecified amount. Since that prespecified amount is always positive, we can view the restrictions on margin loans as solvency constraints. However, if an investor can access unsecured credit, he or she can take out an unsecured loan to keep the account above the prespecified level while violating the solvency constraint.

\section{$3 \quad$ Institutional Considerations}

In this section, we look at ways investors can increase their leverage. We first look at margin loans, which explicitly allow investors to use equity as collateral for loans. We then look at two alternative methods for achieving leverage, both of which implicitly allow investors to borrow against equity holdings. The two alternatives are futures and leveraged mutual funds. In the section, we seek both to give an overall idea of the institutional barriers to collateralized borrowing and to generate parameters for our simulations. Our discussion here parallels similar discussions in a good finance textbook like Hull (2000), but our focus on the small investor differentiates our analysis, as finance textbooks generally focus on investment opportunities for large, wealthy investors.

All three investment programs discussed in this section allow investors to achieve leverage by borrowing against equity holdings. But the terminology is sometimes confusing or inconsistent. The leverage one can get on a margin loan is a function of the margin requirement; the leverage one can get using futures is a function of something called a "performance bond." To allow for comparison of these methods, we standardize our measurement of leverage, using an intuitive criterion: the "down payment" required for a particular level of investment. That is, if the down payment is 10 percent, then one needs $\$ 10,000$ to make a $\$ 100,000$ investment in equity. We also measure the wedge between the interest rate on collateralized borrowing and the rate of return on riskless bonds.

\subsection{Margin Loans}

The principle of a margin loan is quite simple. But how do they work in practice? In Section 3.1.1, we discuss the basic principles and jargon of margin loans. In section 
3.1.2, we discuss how the securities laws limit the availability of margin loans. Finally, in section 3.1.3, we look at the availability of margin loans at several leading brokerage houses.

\subsubsection{How They Work}

To explain how margin loans work, we first need to define some terms. A margin loan is a loan collateralized by holdings of equity. The value of the loan is called the debit balance. Using the debit balance, we can define the margin percentage as follows:

$$
\text { Margin Percentage }=\frac{\text { Value of securities }- \text { Debit balance }}{\text { Value of securities }}
$$

Brokerage firms typically specify two minimum margin percentages. The initial margin is the minimum margin percentage allowed when one borrows. Suppose (as is generally the case in reality) that the initial margin is 50 percent. Then, an investor who owns $\$ 100,000$ in stock (say, 1000 shares at $\$ 100$ each), can take out a $\$ 50,000$ loan.

\begin{tabular}{cccc}
\hline Value of Securities & Debit Balance & Margin & Margin Percent \\
\hline$\$ 100,000$ & $\$ 50,000$ & $\$ 50,000$ & $50 \%$ \\
\hline
\end{tabular}

If the value of the stock increases, one can borrow more money. If the value of the stock falls, however, the investor need not immediately sell stock nor pay back part of the loan. The investor is now required only to keep the margin percentage above the maintenance margin. Suppose the maintenance margin is 25 percent, and suppose the share price falls to $\$ 66 \frac{2}{3}$ a share.

\begin{tabular}{cccc}
\hline Value of Securities & Debit Balance & Margin & Margin Percent \\
\hline$\$ 66,667$ & $\$ 50,000$ & $\$ 16,667$ & $25 \%$ \\
\hline
\end{tabular}

Since the margin percentage is still at or above 25 percent, this investor need not do anything. However, if the margin percentage falls further, the brokerage will make a margin call, demanding that the investor raise the margin percentage above the maintenance margin level. For example, if the share price falls to $\$ 50$ a share, then the margin percentage will be zero, and the investor must either reduce borrowing (by putting up more cash) or sell stock.

\begin{tabular}{cccc}
\hline Value of Securities & Debit Balance & Margin & Margin Percent \\
\hline$\$ 50,000$ & $\$ 50,000$ & $\$ 0$ & $0 \%$ \\
\hline
\end{tabular}




\subsubsection{Legal Issues}

Before 1934, there were no statutory limits on margin credit. Brokerage firms argued that margin loans were a way for investors with little wealth to share in the benefits of the stock market, and the exchanges made little effort to limit margin borrowing. In 1921-1922, the New York Stock Exchange did insist that investors maintain a margin percentage of 10 percent, but it was not until the crash of 1929 that exchanges tightened margin requirements in any meaningful way - raising the initial margin requirement to $1 / 3$ in that year.

The Securities Exchange Act of 1934 was the first legislative effort to control margin credit. The 1934 act gave the Federal Reserve authority over margin credit, authorizing the Fed to set both initial and maintenance margin percentages, with the proviso that initial margin percentages exceed 45 percent.

The Federal Reserve Board sets minimum margin requirements for broker-dealer loans, using something called Regulation T. Until 1974, the Fed considered initial margin percentages as an active component of monetary policy and changed them fairly often. Table 1 shows that the Fed changed initial margin requirements on an almost annual basis, with initial margin percentages reaching 100 percent in 1946 and 90 percent on two other occasions. Individual exchanges set maintenance margins, subject to the approval of the SEC; typically, maintenance margins are set at 25 percent. However, as we show below, these minimums are rarely binding, as brokers usually choose to set maintenance margins at a higher level.

Several other features of the regulation of margin borrowing are worth noting. First, some types of securities are exempt from margin requirements: (1) Mortgages backed by real property (Rule 3a12-5 of 1934 Act), so long as the credit is collateralized by the same property, there are regular mandatory payments on the principal and interest on the credit, and the lender is not affiliated in any way with the issuing broker-dealer; and (2) "direct participation program" securities (Rule 3a12-9 of the 1934 Act), covering securities associated with venture capital or private equity. Second, there are other limitations for specific assets. One can use a foreign asset or an over-the-counter security as collateral only if the Fed has specifically approved the asset in question for margin purposes. In addition, investors cannot use mutual funds as collateral until they have held the fund for 30 days. Third, margin regulations do not apply to accounts owned by U.S. investors who are located outside the United States, and brokerage firms are apparently not shy about assisting their high-net-worth customers in evading margin requirements through offshore accounts. Finally, investors cannot use as collateral for loans, investments in some tax-deferred accounts like IRAs. 


\subsubsection{In Real Life}

Table 2 summarizes access to margin loans at various brokerage houses. In principle, most brokerages allow investors an initial margin percentage of 50 percent and a maintenance margin of 35 percent, but almost all firms impose additional restrictions, usually on stocks with low prices. For example, Vanguard does not allow any initial margin borrowing on shares trading below five dollars. Firms that do not explicitly limit margin borrowing for stocks with low prices do so implicitly in their maintenance requirements. Fidelity requires that an investor maintain a margin of at least three dollars per share or 100 percent if the share trades for less than three dollars.

Interest rates on margin loans vary considerably across firms. For small loans $(<\$ 10,000)$, interest rates range from 7 percent at Brown and Company to 10.5 percent at Charles Schwab. At the time the table was constructed, the return on shortterm Treasury notes was 3.71 percent, meaning that the spread on small-denomination margin loans was between 300 and 650 basis points. Interest rates also vary dramatically with the size of the loan. For example, at Fidelity, an investor who borrows an amount less than $\$ 10,000$ pays 9.825 percent; an investor who borrows more than $\$ 500,000$ pays only 4.75 percent. The rates charged by brokerages appear puzzlingly

high, given that the brokerage has legal custody of the collateral and the authority to close out a position whenever the value of the collateral approaches the value of the loan.

Brokerages also have minimum investment requirements just to open an account, and these requirements may exceed the size of the loan. For example, Brown and Company requires a minimum of $\$ 15,000$ to open an account. Brown and Company also requires that investors have a minimum net worth, exclusive of home equity, of $\$ 50,000$.

\subsubsection{Leverage with Margin Loans}

Overall, how much leverage do margin loans allow? The initial margin requirement of 50 percent implies that investors can buy equity with a 50-percent down payment. It is true that low-priced securities require higher down payments and that investors cannot use margin loans as collateral for 30 days; however, our focus is on long-term investors investing in well-diversified portfolios, so we can ignore these issues. There appears to be enormous variation in the wedge between interest rates on collateralized debt and rates on the riskless asset, both across firms and by the size of the loan. But it seems that a small investor is unlikely to borrow with a wedge of less than 3 percent. 


\subsection{Futures}

In theory, futures allow investors to get unlimited leverage. In practice, however, the ability to get leverage using futures is limited. In this section, we first discuss how futures work in theory and in practice. We then discuss how the practical limitations affect small investors.

\subsubsection{How Futures Work}

A future is a commitment by an investor to buy or sell an asset at a given time at an agreed price. We consider an "e-Mini S\&P contract." ${ }^{2}$ On December 12, 2002, by buying an e-Mini S\&P, an investor agrees to buy 50 times the S\&P 500 index for $\$ 48,050$ at the end of March 2003; another investor agrees to sell 50 times the S\&P 500 for $\$ 48,050$ at the end of March 2003. ${ }^{3}$ No money changes hands, so in theory, both the buying and selling investors have $\$ 48,050$ worth of exposure to equity markets without any investment at all. In practice, however, brokerages and exchanges demand money to make sure that investors never (or hardly ever) have trouble fulfilling their promises, requiring an investor to post a "performance bond" with the exchange and insisting on daily settlement. We discuss each of these mechanisms in turn.

What is a performance bond? When an investor either buys or sells a futures contract, he or she is required to post a bond with the exchange. The amount of money is fixed by the exchange (although some brokers require higher amounts). The size of the performance bond generally varies with the size and volatility of the contract, but it is not a fixed fraction. The CME Rulebook states:4 "Performance bond requirements will be as determined by Exchange staff from time to time." The size of the performance bond is not fixed over time either. Again from the $C M E$ Rulebook:

In the event market conditions and price fluctuations at any time shall cause the President to conclude that additional performance bonds are required to maintain an orderly market or to preserve fiscal integrity, the President may call for additional performance bonds to be deposited with

\footnotetext{
${ }^{2} \mathrm{An}$ "e-Mini S\&P" contract is a product available at the Chicago Mercantile Exchange (CME) that enables an investor to purchase small denomination contracts on the S\&P 500 Index.

${ }^{3}$ For expositional simplicity, we fudge the distinction between futures and forwards. What we describe is actually a forward contract. In fact, a buyer of a futures contract agrees to pay the value of the futures contract on the next trading day, unless the next trading day is the expiration day of the contract, in which case he actually purchases the index.

${ }^{4}$ The CME (originally the Chicago Mercantile Exchange) is the largest futures exchange in the world.
} 
the Clearing House during the next banking hour after demand therefor, or at such times as may be specified. Such additional performance bonds may be called from the longs or the shorts or from both.

For example, on December 12, 2002, the CME performance bond requirement for a March 2003 e-Mini S\&P 500 contract was $\$ 3563$, or 7.9 percent of the contract value. Lind-Waldock, a large futures broker, actually demanded more: $\$ 3,938$, or 8.2 percent of the contract value.

What does daily settlement mean? At the end of each trading day, an investor is required, essentially, to settle his transaction as if the contract ended on that day. Consider the e-Mini discussed above. Suppose our investor agreed on December 12, 2002, to sell 50 times the S\&P 500 in March 2003 for $\$ 45,050$. What happens on the following day? On December 13, 2002, the new, agreed-upon price for March 2003 was $\$ 44,325$. To settle this contract, our investor has to pay $\$ 725$, and that amount is deducted from the performance bond.

Settlement raises another question: Now that the exchange has deducted $\$ 725$ from the performance bond, isn't the bond insufficient? Not necessarily. As with margin loans, there is an initial performance bond amount and a maintenance performance bond amount. In this case, the CME maintenance performance bond's value is $\$ 2850$ (Lind-Waldock required $\$ 3,150$ ). If we deduct the $\$ 725$ loss from the original $\$ 3563$ performance bond, we see that the performance bond's value now equals $\$ 2,838$, and the investor needs to post $\$ 12$ to maintain the contract.

The table below illustrates the evolution of this contract over two days in December of 2002 .

\begin{tabular}{lcccc}
\multirow{2}{*}{ Date } & S\&P & Contract & \multicolumn{2}{c}{ Performance bond } \\
& 500 & value & Minimum & Actual \\
\hline $12 / 12 / 02$ (Thurs.) & 901 & $\$ 45050$ & 3563 & 3563 \\
$12 / 13 / 02$ (Fri.) & 886.50 & $\$ 44325$ & 2850 & 2838 \\
\hline
\end{tabular}

\subsubsection{Practical Issues for Small Investors}

According to the above discussion, futures may not allow unlimited leverage, but they allow investors to invest in equity with a down payment of around 8 percent. We now argue that 8 percent may still be an underestimate of the down payment. We focus on two aspects of the futures market that inhibit small investors from realizing the full leverage implicit in futures contracts. We note that, in principle, one can avoid these frictions by pooling one's money with that of other investors, but we direct the reader to the next section where we discuss existing efforts to do so. 
First, futures contracts are lumpy. An investor who wants $\$ 71,250$ worth of exposure to the S\&P 500 cannot buy 1.5816 contracts. He or she must buy either one or two contracts.

Second and more significantly, a long-term investor cannot simply buy a futures contract and hold it. First, as we saw above, one day after going into the futures market, our investor received a margin call. Our investor can do one of several things. First, he or she can put up more money, either by borrowing or by setting aside money before entering into the contract to ensure that most margin calls can be met. However, both of these strategies reduce the effective level of leverage for the investor: the former by raising the interest rate on borrowing, and the latter by increasing the up-front money required for the investment. Second, he or she can simply decide that if there ever were a margin call, he or she would close the position. However, on most sample paths, the return on the asset would then simply reflect the maintenance level of the performance bond. Finally, an investor can reduce exposure when the market goes down and increase exposure when the market goes up. In our example, the value of the performance bond on December 13,2002 , equalled $\$ 2838$. This is not enough for one e-Mini but it is enough for 99.58 percent of one. Unfortunately, as we pointed out above, one can buy only integer values of the contracts. In addition, even if one's investments were large enough to avoid the integer problem, such a strategy would involve almost daily buying and selling of contracts and would therefore incur significant transactions costs.

\subsubsection{Leverage with Futures}

Overall, how much leverage do futures allow? Table 3 shows some institutional features of futures trading at several brokerages. We show above that one can buy equity with an 8-percent down payment using futures. We view this as a lower bound, however. Absence of arbitrage ensures that the effective borrowing rate implicit in futures contracts equals the riskless rate. Thus, there is no wedge.

\subsection{Mutual Funds}

Mutual fund companies offer funds that explicitly aim to leverage broad equity portfolios. Thus, they offer a particularly easy way for investors to get leverage, and, since these funds use options and futures to get leverage, they provide us with a window into the costs and opportunities for leverage provided by options and futures.

Two firms offer mutual funds that leverage the S\&P 500 Index: Rydex and Pro- 
Funds. ${ }^{5}$ Table 4 summarizes information and recent results for these funds. Rydex describes the objectives of its Titan 500 fund as follows:

Rydex Titan 500 Fund seeks investment results that correlate to the performance of the S\&P 500 Index. The fund primarily invests in leveraged instruments, such as futures contracts and options on securities, futures contracts, and stock indices. Futures and options contracts enable the fund to pursue its objective without investing directly in the securities included in the S\&P 500. The fund may also purchase equity securities, engage in equity index swaps, and enter into repurchase agreements. The Fund's advisor will attempt to consistently apply leverage to increase the fund's exposure to 200 percent of the S\&P 500 Index. This fund is nondiversified.

The objectives of the ProFunds UltraBull fund are similar. These firms also offer leveraged positions on other indices like NASDAQ and even offer "bear" funds that aim to return -100 percent of the return on a particular index.

Expense ratios and realized returns on these funds suggest that leverage using futures and options is quite costly. The expense ratios on these funds range from 144 to 245 basis points. For comparison, note that the expense ratio on the Vanguard Index 500, which provides no leverage, is about an order of magnitude smaller.

The realized returns offer even less cause for optimism. Over the year to November 2005, the ProFunds UltraBull Fund earned 10.95 percent, scarcely more than two percentage points above the Vanguard Index 500 Fund. The record over three years yields a larger excess return for the leveraged funds, but the 5-year returns do not appear to be consistent with the stated goals of the fund.

What can we learn about using futures and options from these mutual funds? First, sophisticated fund managers seem unable to provide efficient vehicles for investors to double their exposure to equity. Second, since firms offer a maximum potential leverage of doubling an investment, it seem reasonable to conclude that achieving greater leverage using options is difficult. Obviously, demand factors play a role as well, but if mutual fund firms could offer very high leverage at reasonable prices, one might think they would.

\subsubsection{Leverage with Mutual Funds}

Overall, how much leverage do mutual funds allow? These funds promise to allow a 50 -percent down payment for equity risk. The expense ratios suggest that the effective

\footnotetext{
${ }^{5} \mathrm{~A}$ third, Potomac, appears to have dropped out of the market.
} 
wedge between the riskless rate and the cost of borrowing is on the order of 150 basis points or more.

\section{Simulations}

In this section, we consider a dynamic model of life-cycle portfolio choice in which we allow investors to use equity as collateral for collateralized loans. We have two main findings. First, investors who forgo the realistic leverage opportunities documented above pay a miniscule price - a fraction of a percent of certain-equivalent lifetime consumption. Second, eliminating all restrictions on collateralized debt would allow investors to increase certain-equivalent consumption much more, but the gains depend on how hard it is for investors to take out uncollateralized loans and how bad the worst possible outcome is for stocks.

\subsection{Parameters}

Table 5 shows the basic parameters we use for our simulations. We draw the reader's attention to five aspects of our parameterization.

First, our treatment of collateralized borrowing follows the analysis in Section 2. Our baseline specification allows investors to buy a dollar of equity by putting up only a twenty-five-cent down payment; that is, it allows four-to-one leverage. According to our analysis, such a level of leverage is not difficult to achieve - for example, an investor could buy a share of the Rydex Titan 500 Fund, which theoretically offers a 50-percent down payment, and then take out a margin loan, which means that the down payment would amount to 25 percent altogether. We assume that the collateralized borrowing rate is two-hundred basis points above the lending rate in our baseline case.

Second, we discretize the equity-return process, using the procedure of Tauchen and Hussey (1991). The procedure generates a finite space of return realizations, all of which exceed zero. The level of the minimum return realization affects the use of collateralized borrowing significantly. See Section 4.2 for a discussion.

Third, we assume that the baseline expected return on equity is 6 percent and that the standard deviation of return on equity is 15 percent. Our expected return is at the low end of estimates in the literature, but we show that our results are generally robust to higher expected returns.

Fourth, we use estimates from Davis, Kubler, and Willen (2006) to choose the borrowing rate for uncollateralized debt. We use their baseline specification of an 
8-percent borrowing rate, implying a 6-percentage-point wedge between borrowing rates and lending rates.

Finally, we use estimates of the life-cycle profile of income from Gourinchas and Parker (2002) as adjusted by Davis, Kubler, and Willen (2006). Figure 2 shows the labor income profile of our baseline household.

\subsection{Portfolio Choice}

Our simulations yield several results on the quantitative importance of collateralized borrowing in life-cycle models of portfolio choice.

First, margin requirements must be relatively low and the secured borrowing rate must be low to significantly affect equity demand. The top panel of Figure 3 shows that if the down payment requirement exceeds 50 percent, equity demand hardly increases in response to a lower secured borrowing rate. With a secured borrowing rate of 4 percent, a minimum down payment of $1 / 3$ fails to yield an appreciable increase in equity holding. Looking at the figure, one clearly sees a kink, and that kink corresponds to the point at which the return on the fully leveraged portfolio exceeds the unsecured borrowing rate. Below the kink, investors will pay off debt before they start investing in equity; above the kink, they start investing in equity while still holding unsecured debt, implying that the threshold level of wealth required for stock ownership goes up as we relax collateral requirements. The lower panel of Figure 3 confirms this, showing that younger investors with less wealth own much less equity, and with tighter collateral requirements, than older investors.

Second, the unsecured borrowing rate matters a lot. The top panel of Figure 4 shows equity demand for an investor who faces no margin requirements and can take secured loans at the riskless rate. In other words, margin borrowing is as generous as can be. Raising the unsecured borrowing rate dramatically affects demand for equity anyway, with a rise in rates from 2 percent to 8 percent cutting demand by almost half. Consumption smoothing drives these results. As we discussed in Section 2, unsecured borrowing affects the sensitivity of consumption to asset-return outcomes and thus the risk-neutral probabilities.

Third, bad states matter a lot. To see why, consider a model with no unsecured borrowing. In this case, the largest possible loss an investor can withstand in the next period equals his income. Working backwards, the investor cannot buy a portfolio that involves, in the worst possible state, losses that exceed his or her income. For example, suppose that an investor has income of $\$ 20,000$ next year and suppose the worst possible stock outcome is -50 percent. Even if the secured interest rate equals zero and there are no margin requirements, the investor cannot purchase more than $\$ 40,000$ 
worth of stock. The effects are pronounced, even in less extreme circumstances. The lower panel of Figure 4 shows that a worst state of 60 -percent loss yields equity demand more than a third lower than a worst possible state of 12 percent.

\subsection{Consumption and Welfare}

We now explore how the collateralized borrowing regime affects lifetime certainequivalent consumption. We see two motivations for this exercise. First, we can calculate the value to investors of the right to use equity as collateral for loans. Since we observe very few investors actually using existing collateral facilities, we can get some understanding of how much utility they lose, if any. Second, some of the limits on collateral are statutory. By exploring utility gains from more liberal collateral regimes, we can measure the welfare loss of existing restrictions.

We measure the welfare gains with respect to two benchmarks. At one end, we have a model with no collateralized debt. We allow investors to take out uncollateralized loans at 8-percent interest but restrict the value of these loans to one year's income. At the other end, we have the Merton (1969) and Samuelson (1969) model in which investors can borrow unlimited amounts at the riskless lending rate. In our example, with a 4-percent equity premium, the top panel of Figure 5 shows that going from our no-margin benchmark to the Merton-Samuelson model leads to an increase in certain-equivalent consumption of more than 50 percent. The question in this section concerns how much of that utility gain we can get by allowing collateralized borrowing. In other words, can collateralized borrowing substitute for uncollateralized borrowing?

The answer, in short, is no. If we assume a down payment requirement of 50 percent, we see that, even with a collateralized borrowing rate of 2 percent, the increase in utility is approximately 1 percent. If we eliminate the down payment requirement altogether, we still get a welfare increase of only about 7 percent. That represents a substantial increase in utility, but it is still nearly an order of magnitude smaller than the increase yielded by unlimited uncollateralized borrowing at the riskless rate. Even if we eliminate the limit on unsecured borrowing (that is, if we allow unlimited collateralized debt at 2 percent and unlimited uncollateralized debt at 10 percent ), the increase in certain-equivalent consumption is still only a quarter as large as it would be if we could go to the full Merton-Samuelson setup. The lower panel of Figure 5 shows that the basic findings are robust to a higher equity return and a lower borrowing rate. With an expected return on equity of 8 percent and a borrowing rate of 8 percent, the gain from eliminating all borrowing restrictions is 120 percent of lifetime certain-equivalent consumption. But the gains in collateralized borrowing 
regimes are generally a small fraction of the gains in the Merton-Samuelson scenario.

That the gains from reducing restrictions on collateralized borrowing should be so much smaller than the gains from eliminating restrictions on uncollateralized borrowing is somewhat surprising. The top left panel of Figure 6 shows the demand for equity over the life cycle under various different regimes. Compare the Merton-Samuelson investor with the investor who can engage in unlimited collateralized borrowing but faces limited uncollateralized borrowing $(B L=1)$. The gap in equity demand is initially quite large, but by retirement, the Merton-Samuelson investor's equity demand is less than double that of the borrowing-constrained investor, and in retirement the gap vanishes. Yet the gain to the Merton-Samuelson investor is about 10 times as large as the gain to the borrowing-constrained investor. Why?

First, the increase in consumption for the Merton-Samuelson investor is much higher, especially early in the life cycle. In fact, initially allowing unlimited margin borrowing for an investor with $B L=1$ leads to a negligible increase in consumption. The intuition is simple. By leveraging up in equity, investors raise their future expected resources. But that increases current consumption only if investors can borrow against these resources easily. If investors can borrow only an amount equal to income, then consumption initially increases hardly at all. If investors can borrow an unlimited amount at 10 percent, consumption goes up somewhat more - by around $\$ 3,000$ initially. And if investors can borrow an unlimited amount at 2 percent, then initial consumption balloons by $\$ 25,000$.

The overall lifetime profile of certain-equivalent consumption is quite different from the profile of consumption. The Merton-Samuelson investor enjoys a much higher level of consumption initially, compared with the borrowing-constrained investor. However, since the Merton-Samuelson investor has much higher exposure to equity, his or her unconditional standard deviation of consumption is much higher, and thus certainequivalent consumption grows much more slowly. By about age 50, certain-equivalent consumption is actually higher for the borrowing-constrained investor with access to collateralized borrowing.

\section{$5 \quad$ Empirical Analysis}

We now explore whether investors actually use the mechanism described in the previous section to generate leverage. We approach the data from three different directions. First, we look at investor-level data from the Survey of Consumer Finances (SCF). Second, we look at margin-loan-use data, both in the aggregate and at the level of individual brokerages. Finally, we look at investor use of leveraged mutual funds. All 
three methods yield one conclusion: Investors do not make much use of the methods described above to obtain leverage. Is this consistent with the theory? In Section 4.2 , we showed that most investors would take out collateralized loans, even with realistically ungenerous collateralized borrowing opportunities. However, in Section 4.3, we showed that the loans increased utility by a miniscule amount. So we view the results below as evidence consistent with the model.

\subsection{Household Data}

The SCF asks households about both margin loans and futures.

On margin loans, the 1998 SCF asked two questions:

1. Do you (or anyone in your family living here) currently have any margin loans at a stock brokerage?

2. Altogether, what is the current balance on these margin loans?

Table 6 shows some information from the SCF, adjusted for oversampling of highnet-worth households using the weights provided by the SCF. What do the SCF data tell us? First, they show that fewer than one percent of households have positive margin loan balances. Since one needs to own stock to get a margin loan, we also look at stockowners: 3.7 percent of stockowners have margin loans, four times as many as the population as a whole. Second, margin-loan holdings are higher for more-highly educated households, even when we condition on stock-owning. Third, margin borrowers account for a somewhat disproportionate share of financial wealth. Column 3 shows the percentage of total stock holdings in the SCF accounted for by margin borrowers. Finally, total margin borrowing is extremely small. The average margin borrowing for households with non-zero margin loans is only $\$ 844$.

On futures, the SCF asks households whether they have "futures contracts [or] stock options" and, if so, the size of the balance of their accounts. Obviously, this question confounds efforts to separate futures from options, and, worse yet, the "futures/options" questions are jointly coded with "Oil/gas/mineral leases or investments." We know only whether an investor has any combination of futures or options or mineral leases. Thus, the SCF can provide us with only an upper bound, but it is an upper bound that appears to be very low. About half of one percent of households reported any of the above investments. Again, more-highly educated people are more likely to have them. Although one can own futures and options (and mineral leases) without owning stock, it is informative to look at households that own stock. Households that own stock are three times as likely to own a combination of futures, 
options, and mineral leases as households that do not own stock, implying an upper bound on futures ownership of less than 2 percent of stock-owning households.

Margin-loan data from brokerages reveal information consistent with the low levels of margin-loan balances in the SCF. Figure 7 shows debit balances in margin accounts at New York Stock Exchange member firms as a percentage of total market capitalization from 1992 to 2002. The figure shows that margin-loan balances have fluctuated considerably over the last 10 years, notably spiking as part of the internet stock boom at the end of 1999 and the beginning of 2000. However, the overall levels of margin debt, even at the peak, were quite low, never exceeding 2.5 percent of total market capitalization and rarely exceeding 2.0 percent. Firm-level information on margin accounts paints a more diffuse picture. Table 7 shows margin debt as a percentage of customer assets at eight brokerage houses. Levels of margin debt vary, with Merrill Lynch customers borrowing only 1.3 percent of their assets and $\mathrm{E}^{*}$ Trade customers borrowing almost 10 percent of their assets. These differences at least partly reflect the fact that Merrill has more retirement accounts, on which customers cannot take margin loans. However, the firms with high margin-debt levels are those typically associated with day-trading of internet stocks. In that sense, this table provides some indirect evidence that households that do use margin loans generally do so for speculative rather than life-cycle reasons.

Finally, we return to the leveraged mutual funds. The right-hand column of Table 4 shows that investment in the leveraged mutual funds discussed in Section 3.3 is small. The most successful fund, the Rydex Titan 500 Index, had $\$ 54.6$ million under management on June 30, 2005, or less than one-tenth of one percent of the assets under management in the unleveraged Vanguard Index 500 Fund.

\section{The Participation Puzzle Revisited}

We now return to an issue posed in the introduction. Does realistic treatment of collateralized debt weaken the argument that borrowing limits are an explanation of why so many investors hold little or no equity? More precisely, researchers have shown that borrowing limits of one kind or another dramatically reduce the gains to holding equity, and, in combination with reasonable transactions costs, can eliminate these gains altogether. But critics contend that such models ignore the distinction between secured and unsecured debt and that the conclusions rest on an unrealistic treatment of the former.

Before continuing, let us briefly recap the participation puzzle - the fact that more people do not hold equity in spite of the historically high returns it has offered 
- and explain why borrowing limits can potentially resolve it. Table 8 (in the first two rows of the first column) shows that, in a reasonably parameterized life-cycle model with unlimited borrowing and lending at the riskless rate, equity investment raises certain-equivalent consumption by 25 percent. We refer to this model as the "standard" model, which most finance students, even at the graduate level, study in some version. No reasonable transaction or information costs can possibly offset the gains to equity trade in the standard model, and so the low incidence of participation shown in the data indeed presents a puzzle. What if we limit borrowing? Table 8 shows that if we modify the standard model by raising the borrowing rate to 10 percent (in the first two rows of the second column), the welfare gain to equity holding shrinks to about 0.5 percent of lifetime consumption. Why do the gains fall so much? In the former case, the expected return on equity exceeds the cost of borrowing, allowing even investors with no liquid wealth to invest profitably in equity. But when the borrowing interest rate exceeds the expected return on equity, no one ever borrows to buy equity, and only investors with liquid wealth reap the gains of equity ownership. For a significant portion of the life cycle, most investors have little liquid wealth and, consequently, little to gain from holding equity. Gomes and Michaelides (2005) exploit this finding by adding a participation cost to the model. Since the gains to equity holding are small, a similarly small participation cost wipes out the benefits of equity holding and leads to non-participation. Hence, the participation puzzle is solved! Vissing-Jørgensen (2002) performs a conceptually similar calculation, but she works from the data and calculates the welfare benefit to SCF households of moving from their current allocation to an optimal allocation. But she implicitly rules out collateralized borrowing by assuming that stock holdings cannot exceed liquid wealth.

Critics of the borrowing-constraints solution to the participation puzzle argue several things. First, they argue that collateralized borrowing opportunities do exist, so that even if we limit unsecured borrowing, investors can still get high leverage. As we show above, the average investor has limited opportunities for collateralized borrowing. Furthermore, the gains to such opportunities fall far short of the gains to unlimited borrowing and lending.

We do not view our results as resolving the participation puzzle, but rather as reducing its magnitude. According to Table 8, with plausible parameters of margin of 25 percent and a secured borrowing rate of 3 percent, a household that holds no equity gives up 1.8 percent of lifetime consumption relative to a household that avails itself of both equity and collateralized borrowing against that equity. 1.8 percent of lifetime consumption remains a rather large sum; Few people would walk away from that. But we think the correct way to view the 1.8 percent is in comparison with 
the 25 percent offered by unlimited borrowing and lending. Realistic treatment of borrowing reduces the participation puzzle by an order of magnitude.

\section{Conclusions}

In this paper, we examined the effects of collateralized borrowing in a realistically parameterized life-cycle portfolio choice problem. As we discussed, previous applied research generally assumed either unlimited collateralized or uncollateralized borrowing, or none at all. Our general conclusion is that models with collateralized borrowing are closer to models with no borrowing at all than to models with unlimited uncollateralized borrowing.

We see two natural directions for future research in this area. First, assets differ enormously in their potential to be used as collateral. One can use at least 90 percent of the value of real estate as collateral for loans. Thus, the fully leveraged return on such assets could potentially exceed the return on the fully leveraged portfolio of equity, possibly explaining why some investors invest in real estate when equity appears to offer a higher return. Second, if we really want to address the participation puzzle, we need to extend our model. In Section 2, we showed that an asset usable as collateral has a shadow return because it relaxes a constraint. The transactions value of bonds could generate a similar shadow return for bonds, and this could explain why households hold bonds when the apparent risk-adjusted return on stocks is higher. 


\section{References}

[1] Brandt, Michael. 2005. Portfolio Choice Problems. In Y. Ait-Sahalia and L.P Hansen, eds., Handbook of Financial Econometrics. Amsterdam: Elsevier.

[2] Campbell, John Y. 1999. Asset prices, consumption, and the business cycle. In John B. Taylor and Michael Woodford, editors, Handbook of Macroeconomics, Volume 1C. Amsterdam: North-Holland.

[3] Campbell, John Y., and Luis Viceira. 2002. Strategic Asset Allocation. New York: Oxford University Press.

[4] Cocco, J., F. Gomes, and P. J. Maenhout. 2005. Consumption and Portfolio Choice over the Life-Cycle. Review of Financial Studies 18: 491-533.

[5] Cocco, J. 2005. Portfolio choice in the presence of housing. Review of Financial Studies 18: 535-567.

[6] Cochrane, John and Lars Hansen. 1992. Asset Pricing Explorations for Macroeconomics. NBER Macro Annual, Olivier Blanchard and Stanley Fischer, editors. Cambridge: MIT Press.

[7] Constantinides, George M., John B. Donaldson, and Rajnish Mehra. 2002. Junior can't borrow: A new perspective on the equity premium puzzle. Quarterly Journal of Economics 117(1): 269-296.

[8] Cox, John, and Chi-fu Huang. 1989. Optimal consumption and portfolio policies when asset prices follow a diffusion process. Journal of Economic Theory 49(1): $33-83$.

[9] Cuoco, Domenico. 1997. Optimal consumption and equilibrium prices with portfolio constraints and stochastic income. Journal of Economic Theory 72(1): 3373.

[10] Cvitanić, Jakša, and Ioannis Karatzas. 1992. Convex duality in constrained portfolio optimization. Annals of Applied Probability 2: 767-818.

[11] Davis, Steven J., Felix Kubler, and Paul S. Willen. 2006. Borrowing costs and the demand for equity over the life-cycle. Review of Economics and Statistics, forthcoming.

[12] Deaton, Angus. 1991. Saving and liquidity constraints. Econometrica 59(5): $1221-1248$. 
[13] Detemple, Jérôme, and Angel Serrat. 2003. Dynamic equilibrium with liquidity constraints. Review of Financial Studies 16(2): 597-629.

[14] El-Karoui, Nicole, and Monique Jeanblanc-Picqué. 1998. Optimization of consumption with labor income. Finance and Stochastics 2: 409-440.

[15] Fortune, Peter. 2000. Margin requirements, margin loans, and margin rates: Practice and principles. New England Economic Review Sep/Oct: 19-44.

[16] Fortune, Peter. 2003. Margin requirements across equity-related instruments: How level is the playing field? New England Economic Review 31-51.

[17] Gabaix, Xavier, Arvind Krishnamurthy, and Olivier Vigneron. 2006. Limits of Arbitrage: Theory and evidence from the mortgage-backed securities market. Journal of Finance, forthcoming.

[18] Geanakoplos, John. 2003. Liquidity, default and crashes. In Mathias Dewatripont, Lars Hansen, and Stephen Turnovsky, eds., Advances in Economics and Econometrics II. Cambridge: Cambridge University Press.

[19] Geanakoplos, John, and William Zame. 2002. Collateral and the Enforcement of Intertemporal Contracts. Working Paper.

[20] Gomes, Francisco, and Alex Michaelides. 2005. Optimal life-cycle asset allocation: Understanding the empirical evidence. Journal of Finance 60: 869-904.

[21] Gourinchas, Pierre-Olivier, and Jonathan A. Parker. 2002. Consumption over the life cycle. Econometrica 70(1): 47-89.

[22] Grossman, Sanford, and Jean-Luc Vila. 1992. Optimal dynamic trading with leverage constraints. Journal of Financial and Quantitative Analysis 27(2): 151168.

[23] He, Hua, and Henri Pagès. 1993. Labor income, borrowing constraints, and equilibrium asset prices. Economic Theory 3: 663-696.

[24] He, Hua, and Neil Pearson. 1991a. Consumption and portfolio policies with incomplete markets and short-sales constraints: The infinite dimensional case. Journal of Economic Theory 54: 259-304.

[25] He, Hua, and Neil Pearson. 1991b. Consumption and portfolio policies with incomplete markets and short-sales constraints: The finite dimensional case. Mathematical Finance 1(3): 1-10. 
[26] Heaton, John, and Deborah Lucas. 1997. Market frictions, savings behavior and portfolio choice. Macroeconomic Dynamics 1: 76-101.

[27] Heaton, John, and Deborah Lucas. 2000. Portfolio choice in the presence of background risk. The Economic Journal 110: 1-26.

[28] Huang, Ming and Ayman Hindy. 1995. Asset pricing with linear collateral constraints. Working paper.

[29] Hull, John. 2000. Options, futures and other derivatives. Upper Saddle River, N.J.: Prentice-Hall.

[30] Kubler, Felix, and Paul S. Willen. 2006. Diversification, collateral and high cost borrowing in a life-cycle portfolio choice model. Work-in-progress.

[31] Lustig, Hanno. 2004. The market price of risk and the wealth distribution. UCLA working paper.

[32] Luttmer, Erzo G. J. 1996. Asset pricing in economies with frictions. Econometrica 64(6): 1439-67.

[33] Merton, Robert C. 1969. Lifetime portfolio selection under uncertainty: The continuous time case. Review of Economics and Statistics 51(3): 247-257.

[34] Merton, Robert C. 1975. Theory of finance from the perspective of continuous time. Journal of Financial and Quantitative Analysis 10: 659-674.

[35] Poterba, James M., and Andrew A. Samwick. 1995. Stock ownership patterns, stock market fluctuations, and consumption. Brookings Papers on Economic Activity 2: 295-357.

[36] Samuelson, Paul A. 1969. Lifetime portfolio selection by dynamic stochastic programming. Review of Economics and Statistics 51(3): 239-246.

[37] Shleifer, Andrei, and Robert Vishny. 1997. The limits of arbitrage. Journal of Finance 52(1): 35-55.

[38] Tauchen, George, and Robert Hussey. 1991. Quadrature-based methods for obtaining approximate solutions to nonlinear asset pricing models. Econometrica 59(2): 371-96.

[39] Tepla, Lucie. 2000. Optimal portfolio policies with borrowing and short-sale constraints. Journal of Economic Dynamics and Control 24: 1623-1639. 
[40] Vila, Jean-Luc, and Thaleia Zariphopoulou. 1997. Optimal consumption and portfolio choice with borrowing constraints. Journal of Economic Theory 77: 402-431.

[41] Vissing-Jørgensen, Annette. 2002. Towards an explanation of household portfolio choice heterogeneity: Nonfinancial income and participation cost structures. NBER Working Paper 8884.

[42] Yao, R., and H. Zhang. 2005. Optimal consumption and portfolio choice with risky housing and borrowing constraints. Review of Financial Studies 18: 197239. 
Table 1: Regulation T minimum margins over time. Source: Federal Reserve Board.

\begin{tabular}{cc}
\hline \hline Effective & Rate \\
\hline $10 / 15 / 34$ & $45 \%$ \\
$2 / 1 / 36$ & $55 \%$ \\
$11 / 1 / 37$ & $40 \%$ \\
$2 / 5 / 45$ & $50 \%$ \\
$7 / 5 / 45$ & $75 \%$ \\
$1 / 21 / 46$ & $100 \%$ \\
$2 / 1 / 47$ & $75 \%$ \\
$3 / 30 / 49$ & $50 \%$ \\
$1 / 17 / 51$ & $75 \%$ \\
$2 / 20 / 53$ & $50 \%$ \\
$1 / 14 / 55$ & $60 \%$ \\
$4 / 23 / 55$ & $70 \%$ \\
$1 / 16 / 58$ & $50 \%$ \\
$8 / 5 / 58$ & $70 \%$ \\
$10 / 16 / 58$ & $90 \%$ \\
$7 / 28 / 60$ & $70 \%$ \\
$7 / 10 / 62$ & $90 \%$ \\
$11 / 6 / 63$ & $70 \%$ \\
$6 / 8 / 68$ & $80 \%$ \\
$5 / 6 / 70$ & $65 \%$ \\
$12 / 6 / 71$ & $55 \%$ \\
$11 / 24 / 72$ & $65 \%$ \\
$1 / 3 / 74$ & $50 \%$ \\
\hline \hline
\end{tabular}


Table 2: Access to margin loans at various brokerages. Some interest rates for comparison, as of 11/18/2005 - Call Money (Broker Call Rate): 5.75; Prime Rate: 6.75; Federal Funds: 4.00; Treasury Bills (90 Day): 3.71; Discount Rate: 5.00.

\begin{tabular}{|c|c|c|c|c|c|}
\hline \multirow[b]{2}{*}{ Firm } & \multirow{2}{*}{$\begin{array}{l}\text { Initial Margin } \\
\text { Requirement } \\
\text { (Exchange-Listed And } \\
\text { Most Nasdaq Listed) }\end{array}$} & \multirow{2}{*}{$\begin{array}{l}\text { Maintenance Requirement } \\
\text { (Exchange-Listed And } \\
\text { Most Nasdaq Listed) }\end{array}$} & \multicolumn{3}{|c|}{ Interest Rate Schedule } \\
\hline & & & Debit balance $(\$)$ & $\begin{array}{l}\text { Interest rate } \\
\text { (above base } \\
\text { rate in } \% \text { pts) } \\
\end{array}$ & $\begin{array}{c}\text { Current base } \\
\text { rate (as of } \\
11 / 2 / 05) \\
\end{array}$ \\
\hline \multirow{4}{*}{$\begin{array}{l}\text { The Vanguard } \\
\text { Group }\end{array}$} & \multirow{4}{*}{$\begin{array}{l}50 \% \text { of net amount (below } \$ 5 \\
\text { per share requires } 100 \% \\
\text { payment) }\end{array}$} & \multirow{4}{*}{$\begin{array}{l}\text { Greater of } 35 \% \text { of market } \\
\text { value or } \$ 3 \text { per share }\end{array}$} & $<20,000$ & 1.25 & \multirow{4}{*}{7.50} \\
\hline & & & $20,000-49,999.99$ & 0.75 & \\
\hline & & & $50,000-99,999.99$ & 0.50 & \\
\hline & & & $100,000+$ & 0.25 & \\
\hline \multirow{6}{*}{$\begin{array}{l}\text { Fidelity } \\
\text { Investments }\end{array}$} & \multirow{6}{*}{$50 \%$ of purchase price } & \multirow{6}{*}{$\begin{array}{l}\text { Greater of } 35 \% \text { of purchase } \\
\text { price, } \$ 3 \text { per share or } 100 \% \text { of } \\
\text { purchase price if price less } \\
\text { than } \$ 3 \text { ( } \$ 4 \text { for non } \\
\text { NYSE-listed and Nasdaq) }\end{array}$} & $<10,000$ & 2.00 & \multirow{6}{*}{7.825} \\
\hline & & & $10,000-24,999.99$ & 1.50 & \\
\hline & & & $25,000-49,999.99$ & 1.00 & \\
\hline & & & $50,000-99,999.99$ & 0.50 & \\
\hline & & & $100,000-499,999.99$ & 0.00 & \\
\hline & & & $500,000+$ & -3.075 & \\
\hline \multirow{8}{*}{$\begin{array}{l}\text { Charles } \\
\text { Schwab }\end{array}$} & \multirow{8}{*}{$\begin{array}{l}50 \% \text { of purchase cost. } \$ 5,000 \\
\text { in cash or marginable } \\
\text { securities minimum. } \\
\text { Marginable securities include } \\
\text { most exchange traded stocks } \\
\text { and Nasdaq-listed securities } \\
\text { above } \$ 5 \text { per share }\end{array}$} & \multirow{8}{*}{$\begin{array}{l}30 \% \text { of total account value } \\
\text { unless volatile or low-priced } \\
\text { security, where it will be } \\
\text { higher (up to } 100 \% \text { ) }\end{array}$} & $<10,000$ & 3.00 & \multirow{8}{*}{7.50} \\
\hline & & & $10,000-24,999$ & 2.00 & \\
\hline & & & $25,000-49,999$ & 1.50 & \\
\hline & & & $50,000-99,999$ & 0.50 & \\
\hline & & & $100,000-249,999$ & 0.375 & \\
\hline & & & $250,000-999,999$ & 0.25 & \\
\hline & & & $1,000,000-2,499,999$ & -0.25 & \\
\hline & & & $2,500,000+$ & -0.50 & \\
\hline \multirow{6}{*}{$\begin{array}{l}\text { Salomon Smith } \\
\text { Barney } \\
\text { (Portfolio } \\
\text { Credit Line } \\
\text { and non Select } \\
\text { Client) } \\
\end{array}$} & \multirow{6}{*}{$\begin{array}{l}50 \% \text { of purchase cost (below } \\
\$ 5 \text { per share requires } 100 \% \\
\text { payment) }\end{array}$} & \multirow{6}{*}{$\begin{array}{l}30 \% \text { for stocks priced }>\$ 5 \\
100 \% \text { for price }=\$ 5 \text { or less }\end{array}$} & $<10,000$ & 2.75 & \multirow{6}{*}{5.625} \\
\hline & & & $10,000-24,999$ & 2.50 & \\
\hline & & & $25,000-49,999$ & 1.875 & \\
\hline & & & $50,000-74,999$ & 1.375 & \\
\hline & & & $75,000-99,999$ & 1.00 & \\
\hline & & & $100,000+$ & 0.75 & \\
\hline \multirow{10}{*}{$\begin{array}{l}\text { UBS Paine } \\
\text { Webber }\end{array}$} & \multirow{10}{*}{$\begin{array}{l}50 \% \text { of marginable stock, } \\
\text { which generally includes those } \\
\text { equity securities registered on } \\
\text { a national securities exchange } \\
\text { or Nasdaq }\end{array}$} & \multirow{10}{*}{$\begin{array}{l}30 \% \text { for most margin accounts } \\
\text { consisting of diversified } \\
\text { equities }\end{array}$} & $<25,000$ & 3.50 & \multirow{10}{*}{5.875} \\
\hline & & & $25,000-49,999$ & 3.125 & \\
\hline & & & $50,000-74,999$ & 2.75 & \\
\hline & & & $75,000-99,999$ & 2.125 & \\
\hline & & & $100,000-249,999$ & 1.125 & \\
\hline & & & $250,000-499,999$ & 0.75 & \\
\hline & & & $500,000-999,999$ & 0.375 & \\
\hline & & & $1,000,000-4,999,999$ & 0.00 & \\
\hline & & & $5,000,000-9,999,999$ & -0.375 & \\
\hline & & & $10,000,000+$ & -0.750 & \\
\hline
\end{tabular}




\begin{tabular}{|c|c|c|c|c|c|}
\hline \multirow[b]{2}{*}{ Firm } & \multirow{2}{*}{$\begin{array}{l}\text { Initial Margin } \\
\text { Requirement } \\
\text { (Exchange-Listed And } \\
\text { Most Nasdaq Listed) } \\
\end{array}$} & \multirow{2}{*}{$\begin{array}{l}\text { Maintenance Requirement } \\
\text { (Exchange-Listed And } \\
\text { Most Nasdaq Listed) }\end{array}$} & \multicolumn{3}{|c|}{ "Interest Rate Schedule } \\
\hline & & & Debit balance $(\$)$ & $\begin{array}{c}\text { Interest rate } \\
\text { (above base } \\
\text { rate in } \% \text { ) }\end{array}$ & $\begin{array}{l}\text { Current base } \\
\text { rate (as of } \\
7 / 8 / 02 \text { ) }\end{array}$ \\
\hline \multirow{6}{*}{ Harrisdirect } & \multirow{6}{*}{$\begin{array}{l}50 \% \text { of net amount for listed } \\
\text { or Fed-approved OTC equity. } \\
100 \% \text { of net amount for other } \\
\text { equity and all warrants. } \\
\text { Additionally, they maintain a } \\
\text { list of non marginable } \\
\text { securities }\end{array}$} & \multirow{6}{*}{$\begin{array}{l}\text { Greater of } 30 \% \text { of market } \\
\text { value or } \$ 3.00 \text { per share for } \\
\text { listed or Fed-approved OTC } \\
\text { equity. } 100 \% \text { of market value } \\
\text { for other equity and warrants }\end{array}$} & $\overline{c<25,000}$ & 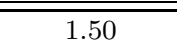 & \multirow{6}{*}{7.50} \\
\hline & & & $25,000-49,999$ & 1.00 & \\
\hline & & & $50,000-99,999$ & 0.50 & \\
\hline & & & $100,000-249,999$ & 0.25 & \\
\hline & & & $250,000-999,999$ & 0.00 & \\
\hline & & & $1,000,000+$ & -0.50 & \\
\hline \multirow{6}{*}{ Ameritrade } & \multirow{6}{*}{$\begin{array}{l}50 \% \text { of purchase cost for } \\
\text { eligible securities }\end{array}$} & \multirow{6}{*}{$\begin{array}{l}25 \% \text { of market value of } \\
\text { securities or } \$ 2.50 \text { per share, } \\
\text { whichever is greater. }\end{array}$} & $<25,000$ & 1.00 & \multirow{6}{*}{8.50} \\
\hline & & & $25,000-49,999$ & 0.75 & \\
\hline & & & $50,000-99,999$ & -0.25 & \\
\hline & & & $100,000-249,999$ & -0.50 & \\
\hline & & & $250,000-999,999$ & -0.75 & \\
\hline & & & $1,000,000+$ & -1.50 & \\
\hline \multirow{6}{*}{$\begin{array}{l}\text { Brown \& } \\
\text { Company (JP } \\
\text { Morgan Chase }\end{array}$} & \multirow{6}{*}{$\begin{array}{l}50 \% \text { initial requirement for } \\
\text { listed and approved Nasdaq } \\
\text { stock above } \$ 4.00 \text { per share. } \\
100 \% \text { for stocks at } \$ 4.00 \text { per } \\
\text { share or below }\end{array}$} & $30 \%$ for listed and approved & $<25,000$ & 1.00 & \multirow{6}{*}{6.00} \\
\hline & & Nasdaq stock above $\$ 5.00$ per & $25,000-49,999$ & 0.75 & \\
\hline & & share. $50 \%$ for stock valued at & $50,000-99,999$ & 0.25 & \\
\hline & & $\$ 4.01$ to $\$ 5.00$ per share. & $100,000-249,999$ & 0.00 & \\
\hline & & $100 \%$ for stock at $\$ 4.00$ per & $250,000-999,999$ & -0.50 & \\
\hline & & share and below & $1,000,000+$ & -1.25 & \\
\hline
\end{tabular}

Source: All information was obtained on the public web-sites of each respective financial firm. 
Table 3: Institutional features of the futures market.

\begin{tabular}{|c|c|c|c|}
\hline Firm & Minimum Balance & $\begin{array}{l}\text { Initial Margin Requirement } \\
\text { (Performance Bond) }\end{array}$ & Commission Schedule \\
\hline \multirow[t]{3}{*}{$\begin{array}{l}\text { Direct Trade (deep } \\
\text { discount futures and } \\
\text { options brokerage) }\end{array}$} & $\begin{array}{l}\text { Initial balance requirement } \\
\text { of } \$ 2,000 . \text { No account size } \\
\text { maintenance requirement }\end{array}$ & $\begin{array}{l}\text { Offers exchange minimum margins for } \\
\text { overnight positions. Day trade } \\
\text { margins generally of overnight margin } \\
\text { requirement }\end{array}$ & \multirow[t]{3}{*}{$\begin{array}{l}\$ 3.50 \text { per side (E-Mini contracts). } \$ 7.00 \text { per side } \\
\text { (accounts opened with } \$ 5,000 \text { or more but no } \\
\text { maintenance requirement). } \$ 14.50 \text { per side (accounts } \\
\text { opened with } \$ 2,000 \text { to } \$ 5,000 \text { ) }\end{array}$} \\
\hline & $\begin{array}{l}\text { E-Mini S\&P } 500 \text { (contract } \\
\text { value }=\$ 56,800)\end{array}$ & $\$ 3,563, \$ 2,850$ maintenance & \\
\hline & $\begin{array}{l}\text { Dow Jones (contract value } \\
=\$ 97,980)\end{array}$ & $\$ 5,400, \$ 4,000$ maintenance & \\
\hline \multirow[t]{3}{*}{$\begin{array}{l}\text { Lind-Waldock } \\
\text { (affiliated with } \\
\text { Schwab) }\end{array}$} & $\begin{array}{l}\text { Initial balance requirement } \\
\text { of } \$ 5,000\end{array}$ & $\begin{array}{l}\text { Range from } 2 \% \text { to } 15 \% \text { of value of } \\
\text { contract with majority around } 5 \%\end{array}$ & \multirow[t]{3}{*}{$\begin{array}{l}\$ 2.50 \text { to } \$ 17.50 \text { per side. } \$ 3 \text { round turn (buy and sell a } \\
\text { contract in any order) rebate for online trading }\end{array}$} \\
\hline & $\begin{array}{l}\text { E-Mini S\&P } 500 \text { (contract } \\
\text { value }=\$ 56,800)\end{array}$ & $\$ 3,938, \$ 3,150$ maintenance & \\
\hline & $\begin{array}{l}\text { Dow Jones (contract value } \\
=\$ 97,980)\end{array}$ & $\$ 5,400, \$ 4,000$ maintenance & \\
\hline $\begin{array}{l}\text { Man Financial } \\
\text { (another large futures } \\
\text { brokerage) }\end{array}$ & No minimum indicated & $\begin{array}{l}\text { Offers exchange minimum margin } \\
\text { requirements (subject to change } \\
\text { without notice). Normally around } 5 \% \text {. }\end{array}$ & $\begin{array}{l}\text { One-on-One (access to own team of brokers/traders) - } \$ 15 \\
\text { to } \$ 21.50 \text { per side. Discount - } \$ 2 \text { to } \$ 15 \text { per side. Rate } \\
\text { dependent on style of trading, number of contracts } \\
\text { typically traded, number traded per month, size of } \\
\text { account }\end{array}$ \\
\hline $\begin{array}{l}\text { Paragon Investments } \\
\text { (full service, online, } \\
\text { and discount account } \\
\text { options) }\end{array}$ & $\begin{array}{l}\text { Full sevice (broker assisted) - } \\
\text { no account minimum. } \\
\text { Online and discount - } \$ 3,000 \\
\text { account minimum } \\
\text { (speculative), } \$ 1,000 \text { (hedge) }\end{array}$ & $\begin{array}{l}\text { Offers exchange minimum margin } \\
\text { requirements }\end{array}$ & $\begin{array}{l}\text { Full service }-\$ 17.50 \text { to } \$ 29.90 \text { per side. Online - } \$ 6 \text { to } \\
\$ 14.90 \text { per side. Discount }-\$ 7.50 \text { to } \$ 17.50 \text { per side }\end{array}$ \\
\hline \multirow[t]{3}{*}{$\begin{array}{l}\text { Xpresstrade (one of } \\
\text { first online futures } \\
\text { brokers) }\end{array}$} & $\begin{array}{l}\$ 5,000 \text { minimum initial } \\
\text { account }\end{array}$ & $\begin{array}{l}\text { Offers exchange minimum margin } \\
\text { requirements. Normally around } 5 \% \text { to } \\
10 \%\end{array}$ & \multirow{3}{*}{$\begin{array}{l}1-80 \text { contracts } / \text { mth }-\$ 11 \text { per side per contract. } 81-200- \\
\$ 9 \text { (E-mini market orders), } \$ 10 \text { (other market orders), } \$ 11 \\
\text { (limit, stop, others). } 201-300 \text { - } \$ 8.50 \text { (E-mini market } \\
\text { orders), } \$ 9.50 \text { (other market orders), } \$ 10.50 \text { (limit, stop, } \\
\text { others). Over } 300 \text { - } \$ 8 \text { (E-mini market orders), } \$ 9 \text { (other } \\
\text { market orders), } \$ 10 \text { (limit, stop, others) }\end{array}$} \\
\hline & $\begin{array}{l}\text { E-Mini S\&P } 500(\text { contract } \\
\text { value }=\$ 56,800)\end{array}$ & $\$ 3,562, \$ 2,850$ maintenance & \\
\hline & $\begin{array}{l}\text { Dow Jones (contract value } \\
=\$ 97,980)\end{array}$ & $\$ 5,400, \$ 4,000$ maintenance & \\
\hline
\end{tabular}


Table 4: Mutual funds that leverage the S\&P 500. Vanguard Index 500 included for comparision. Data as of 6/30/05.

\begin{tabular}{lcccccc}
\hline \hline Fund name & $\begin{array}{c}\text { Leverage } \\
\text { in \% }\end{array}$ & $\begin{array}{c}\text { Expense } \\
\text { ratio in \% }\end{array}$ & $\begin{array}{c}\text { 1-yr } \\
\text { return }\end{array}$ & $\begin{array}{c}3-y r \\
\text { return }\end{array}$ & $\begin{array}{c}5-y r \\
\text { return }\end{array}$ & Assets \\
\hline S\&P 500 Index & - & - & 8.72 & 12.85 & -1.74 & \\
Vanguard Index 500 & 100 & 0.18 & 8.60 & 12.70 & -1.85 & $70.89 \mathrm{~B}$ \\
ProFunds UltraBull & 200 & 1.44 & 10.95 & 19.92 & -11.70 & $129.75 \mathrm{M}$ \\
Rydex Titan 500 & 200 & 2.45 & 10.53 & 18.66 & - & $54.63 \mathrm{M}$ \\
\hline \hline
\end{tabular}

Source: http://finance.yahoo.com 
Table 5: Parameter values.

\begin{tabular}{lcc}
\hline \hline Parameter & Baseline & Alternative values \\
\hline RRA & 3 & 2 \\
Discount factor & 0.95 & \\
Age of labor force entry & 21 & \\
Age of retirement & 65 & \\
Age of death & 80 & \\
$r_{U}$ & $8 \%$ & $2 \%, 5 \%, 8 \%, 20 \%, 99 \%$ \\
$\bar{B}$ & 1 & $0.5,2$, unlimited \\
$r_{S}$ & $4 \%$ & $2 \%, 3 \%, 5 \%$ \\
$\bar{M}$ & $25 \%$ & $2 \%, 7 \%, 50 \%, 100 \%$ \\
$r_{L}$ & $2 \%$ & \\
$r_{E}$ & $6 \%$ & $8 \%$ \\
$\operatorname{std} \tilde{r}$ & $15 \%$ & \\
$\operatorname{std} \tilde{\epsilon}$ & $0 \%$ & $15 \%$ \\
$\operatorname{std} \tilde{\eta}$ & $0 \%$ & $12 \%$ \\
\hline \hline
\end{tabular}

Table 6: Who has margin loans? 1998 SCF. Percentages calculated using SCF weights.

\begin{tabular}{l|cccc|ccc}
\hline \hline & \multicolumn{3}{|c|}{$\begin{array}{c}\text { Has margin loans } \\
\text { \% of }\end{array}$} & \multicolumn{3}{c}{ Owns of futures } \\
Group & $\begin{array}{c}\text { \% of } \\
\text { all }\end{array}$ & $\begin{array}{c}\text { stock- } \\
\text { owners }\end{array}$ & $\begin{array}{c}\text { Fin. } \\
\text { wealth }\end{array}$ & $\begin{array}{c}\text { Average } \\
\text { balance }\end{array}$ & $\begin{array}{c}\text { \% of } \\
\text { all }\end{array}$ & $\begin{array}{c}\text { of } \\
\text { stock- } \\
\text { owners }\end{array}$ & $\begin{array}{c}\text { Fin. } \\
\text { wealth }\end{array}$ \\
\hline All & 0.8 & 3.7 & 6.1 & 844 & 0.5 & 1.5 & 2.5 \\
\hline College degree & 1.6 & 5.5 & 6.0 & 1159 & 1.3 & 3.5 & 4.8 \\
Grad. degree & 3.1 & 6.0 & 8.7 & 3298 & 1.2 & 2.1 & 2.7 \\
\hline Age 20-40 & 0.6 & 4.2 & 3.9 & 82 & 0.5 & 1.0 & 1.2 \\
Age 40-60 & 1.2 & 4.0 & 6.6 & 905 & 0.4 & 1.8 & 2.8 \\
Age 60-80 & 0.7 & 3.1 & 6.8 & 2042 & 0.8 & 1.9 & 2.6 \\
\hline \hline
\end{tabular}

Source: 1998 Survey of Consumer Finances 
Table 7: Margin debt at different firms, 1999.

\begin{tabular}{lc}
\hline \hline Entity & Margin debt as \% of customer assets \\
\hline Merrill Lynch & $1.3 \%$ \\
NYSE \& NASDAQ & $1.5 \%$ \\
Paine Webber & $1.6 \%$ \\
Charles Schwab & $2.4 \%$ \\
DLJDirect & $5.3 \%$ \\
TD Waterhouse & $6.1 \%$ \\
Ameritrade & $7.2 \%$ \\
E*Trade & $9.6 \%$ \\
\hline \hline
\end{tabular}

Source: New York Stock Exchange. 
Table 8: Certain-equivalent consumption for various asset choice menus. $r_{U}$ is the unsecured borrowing rate, and $r_{S}$ is the secured borrowing rate. Margin is the "down payment" on an investment; that is, if the margin is 25 percent, you can use only 75 percent of the investment as collateral. For the $r_{U}=10 \%$ case, we assume that total unsecured borrowing cannot exceed annual labor income. All simulations follow baseline assumption in the paper. Expected return on equity is $6 \%$, relative risk aversion is 3 , subjective discount factor is 0.97 . Note that $r_{U}=2 \%$ renders secured credit redundant, hence the "-"s in the relevant locations in the table. Values are CE consumption in $\$ 1000$ s. Percentages (in parentheses) represent increases from the base case of the first row.

\begin{tabular}{|c|c|c|}
\hline & $r_{U}=2 \%$ & $r_{U}=10 \%$ \\
\hline \multicolumn{3}{|c|}{ First, assume no secured debt } \\
\hline (1) No equity & 28.1 & 24.8 \\
\hline (2) Equity, no margin & 35.1 & 24.9 \\
\hline loans & $(25.0 \%)$ & $(0.5 \%)$ \\
\hline \multicolumn{3}{|c|}{ Now add in secured credit... } \\
\hline $\begin{array}{l}\text { (3) } \text { Margin }=50 \% \text {, } \\
r_{S}=4 \%\end{array}$ & - & $\begin{array}{c}25.0 \\
(0.8 \%)\end{array}$ \\
\hline $\begin{array}{l}\text { (4) } \text { Margin }=50 \% \text {, } \\
r_{S}=2 \%\end{array}$ & - & $\begin{array}{c}25.1 \\
(1.2 \%)\end{array}$ \\
\hline $\begin{array}{l}\text { (5) } \text { Margin }=25 \% \text {, } \\
r_{S}=3 \%\end{array}$ & - & $\begin{array}{c}25.2 \\
(1.8 \%)\end{array}$ \\
\hline $\begin{array}{l}\text { (6) Margin }=0 \%, \\
r_{S}=4 \%\end{array}$ & - & $\begin{array}{c}25.3 \\
(2.2 \%) \\
\end{array}$ \\
\hline $\begin{array}{l}\text { (7) } \text { Margin }=25 \%, \\
r_{S}=2 \%\end{array}$ & - & $\begin{array}{c}25.6 \\
(3.2 \%)\end{array}$ \\
\hline $\begin{array}{l}\text { (8) Margin }=0 \%, \\
r_{S}=2 \%\end{array}$ & - & $\begin{array}{c}26.4 \\
(6.7 \%) \\
\end{array}$ \\
\hline
\end{tabular}


Figure 1: The portfolio stairs. See Section 2 for an explanation. Note that the FLP line and the discount rate line coincide between wealth levels $A$ and $E$. The equity line and the discount rate line coincide for wealth levels above $D$. Between wealth levels $D$ and $E$, the FLP, equity and discount rates all coincide.

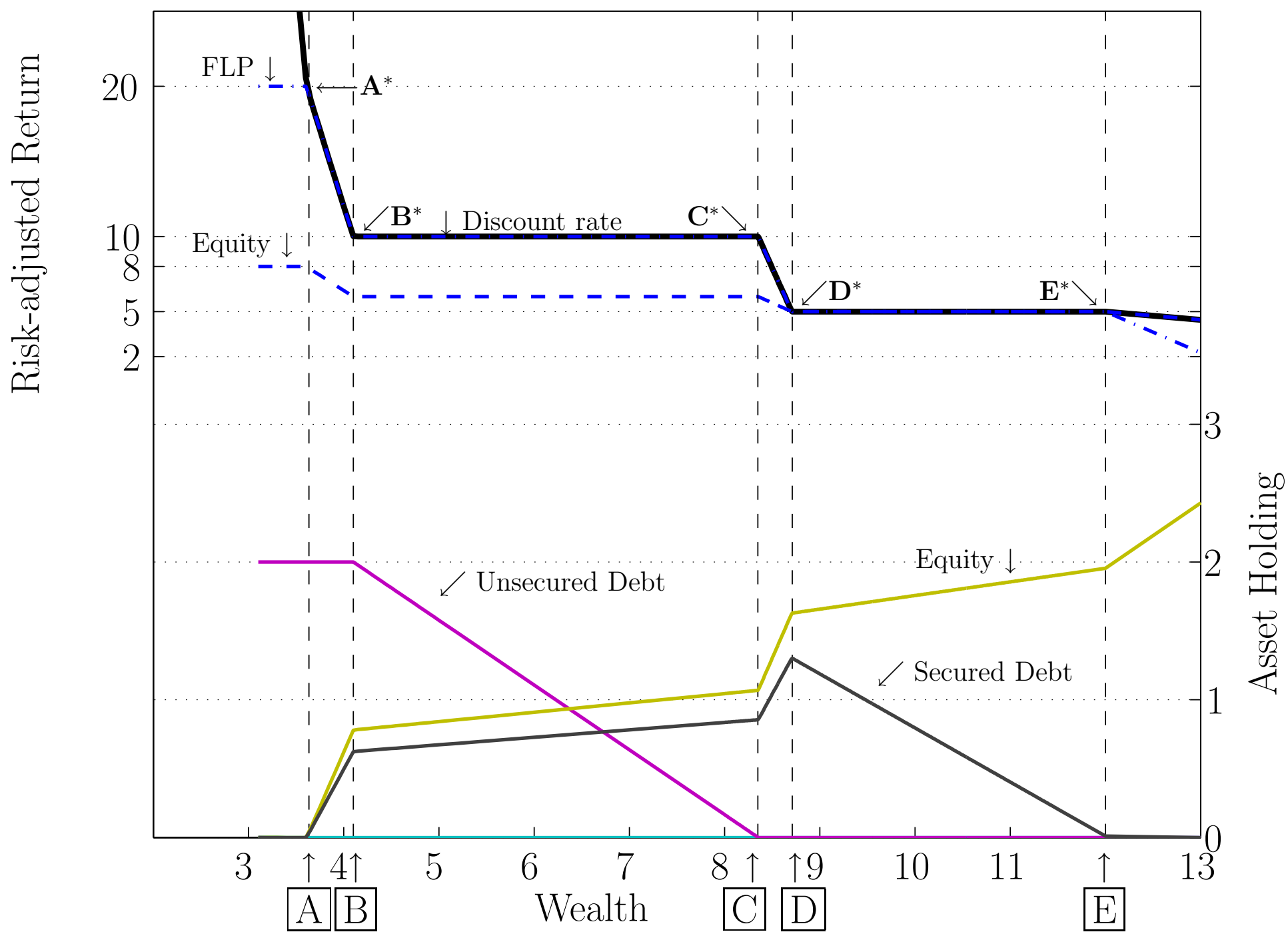


Figure 2: Expected labor income profile. Source: Gourinchas and Parker (2002) and Davis, Kubler, and Willen (2006).

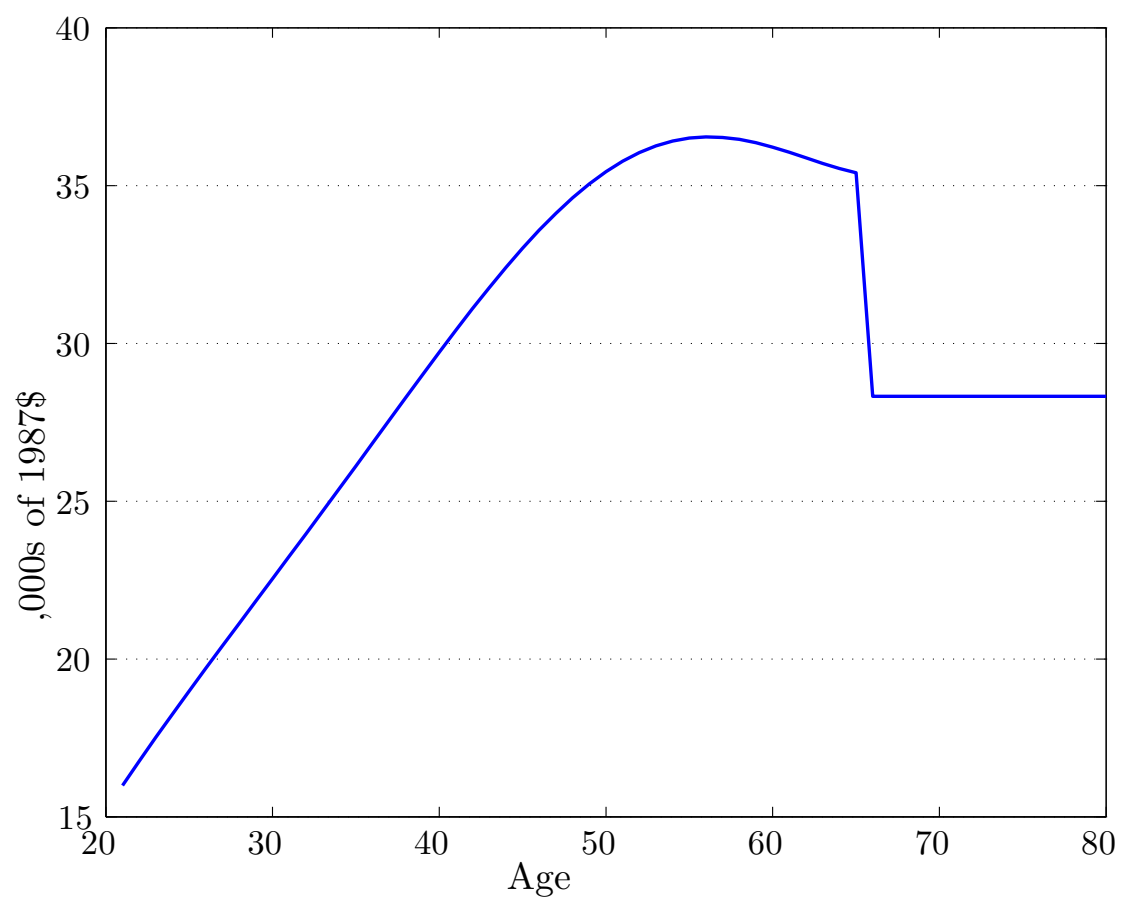


Figure 3: How does collateralized borrowing affect lifetime demand for equity? Top panel shows the effects of changing margin requirements. Bottom panel shows the effects of changing the collateralized interest rate.
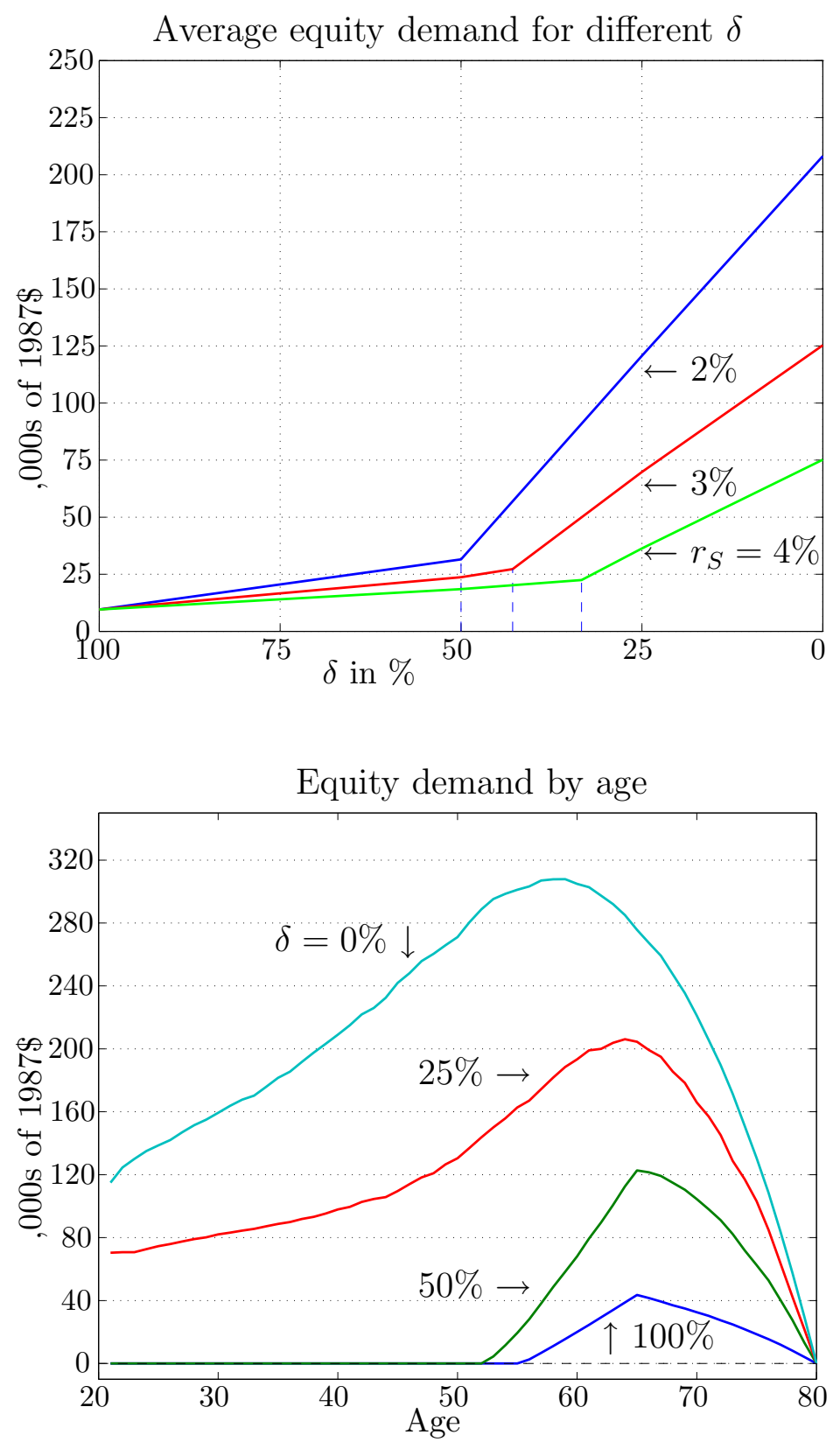
Figure 4: Lifetime demand for equity: the role of uncollateralized borrowing.
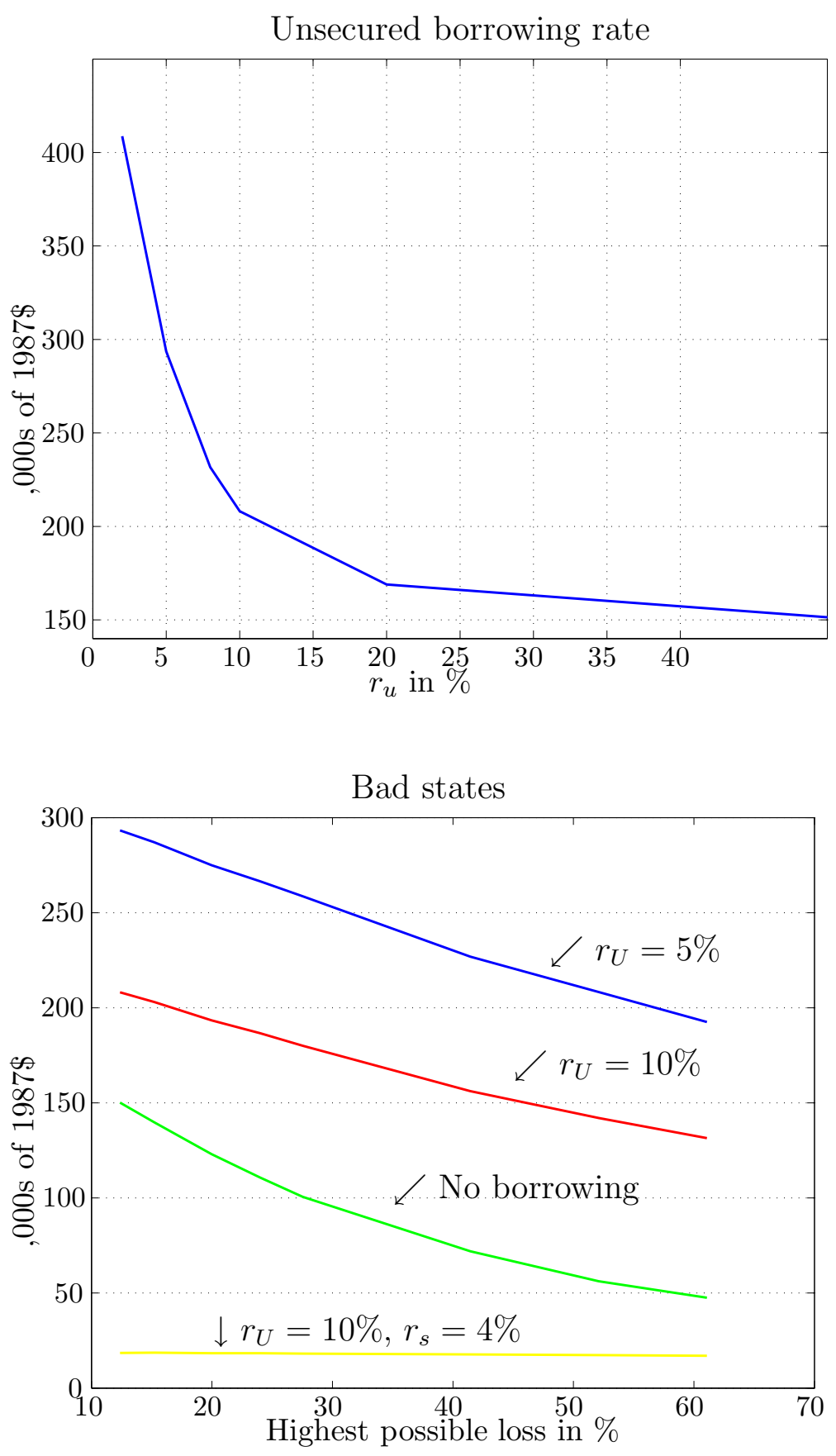
Figure 5: How much does collateralized borrowing raise lifetime certain equivalent consumption?
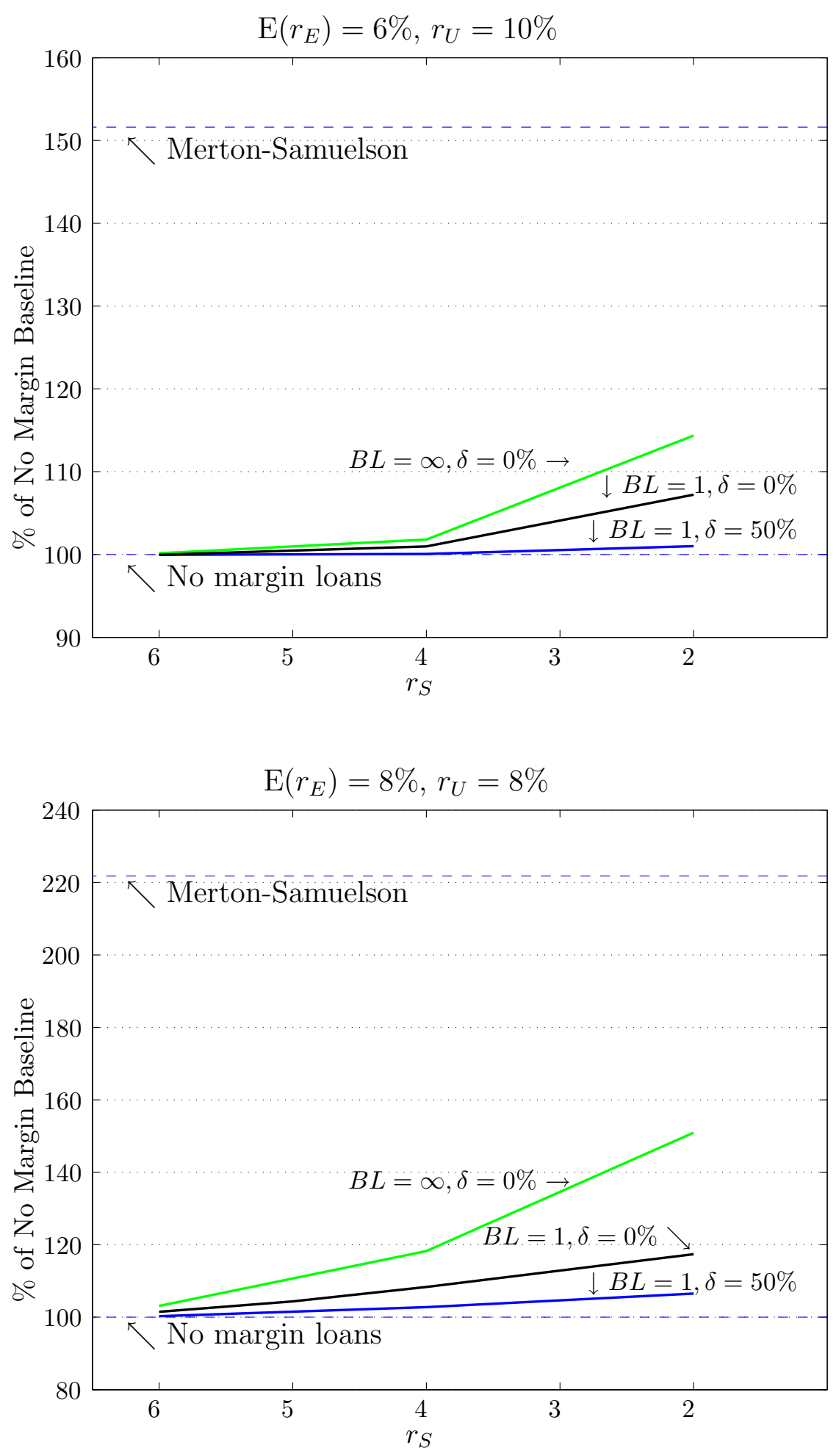
Figure 6: Consumption and welfare over the life cycle.
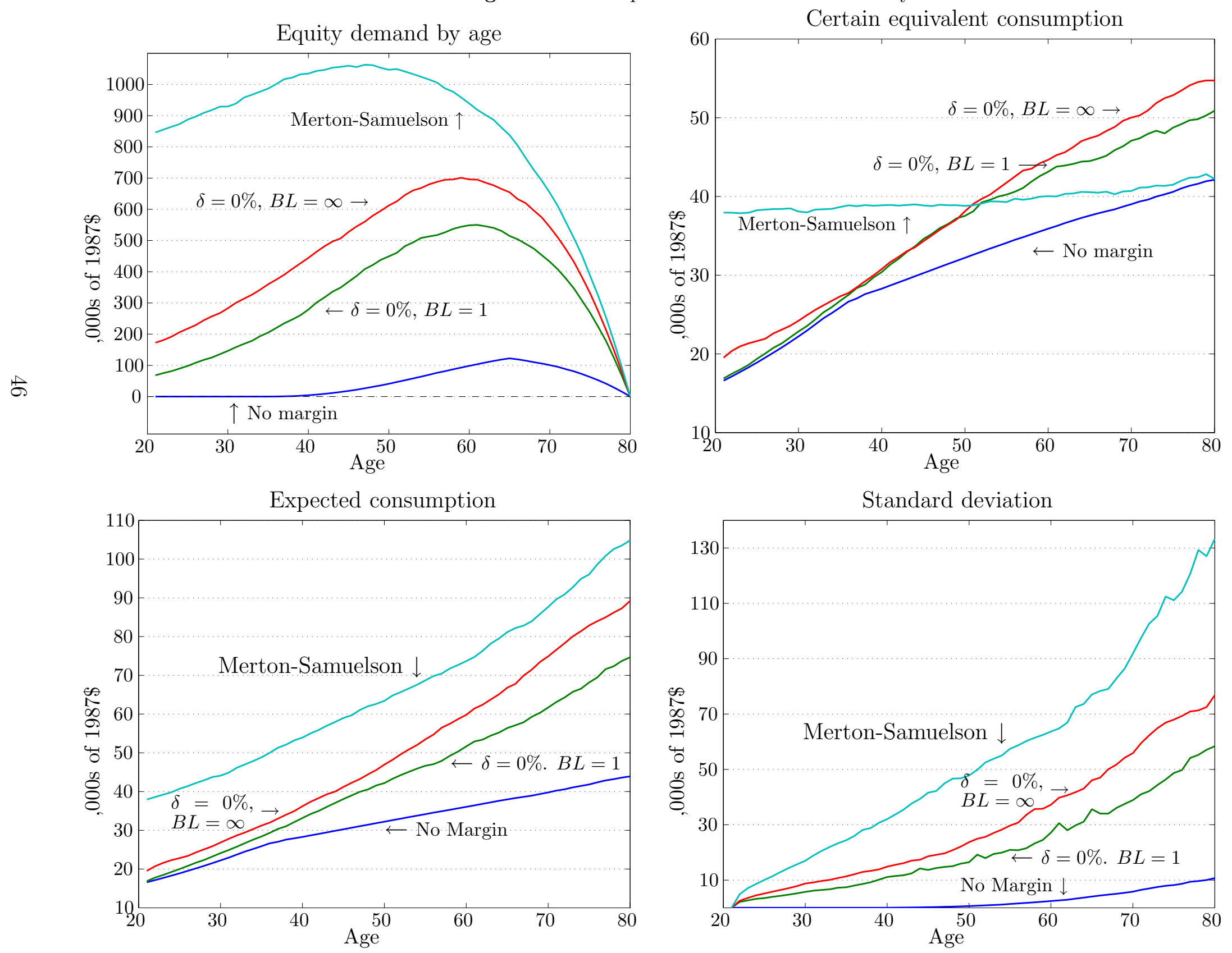
Figure 7: Debit balances at NYSE firms. Figure shows margin debt as a percentage of total market capitalization. Source: New York Stock Exchange.

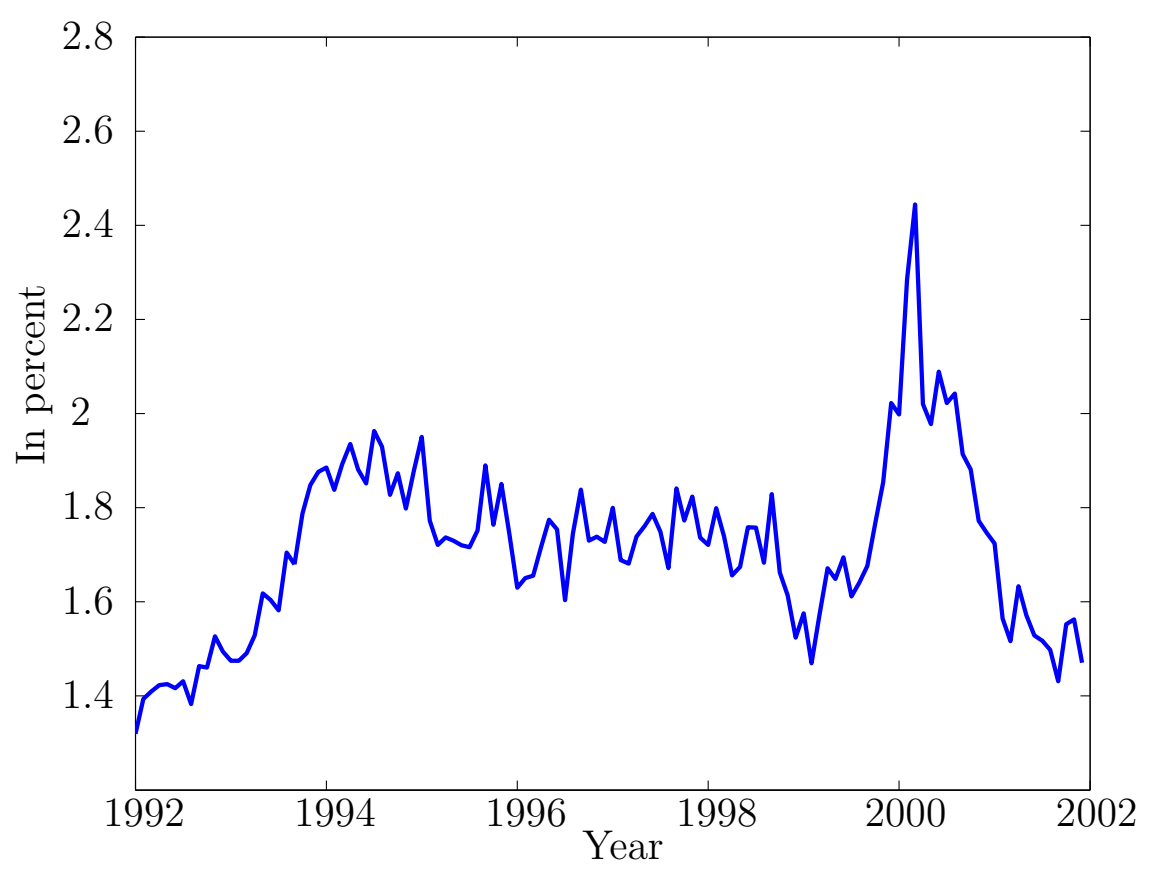

